\title{
Synthesis of Specifically Modified Oligonucleotides for Application in Structural and Functional Analysis of RNA
}

\author{
Nico Rublack, ${ }^{1}$ Hien Nguyen, ${ }^{1}$ Bettina Appel, ${ }^{1}$ Danilo Springstubbe, ${ }^{1}$ \\ Denise Strohbach, ${ }^{1,2}$ and Sabine Müller ${ }^{1}$ \\ ${ }^{1}$ Ernst-Moritz-Arndt-Universität Greifswald, Institut für Biochemie, Felix-Hausdorff-Straße 4, 17487 Greifswald, Germany \\ ${ }^{2}$ Biomers.net GmbH, Sölflinger Straß 100, 89077 Ulm, Germany
}

Correspondence should be addressed to Sabine Müller, smueller@uni-greifswald.de

Received 14 May 2011; Revised 11 July 2011; Accepted 21 July 2011

Academic Editor: Daisuke Miyoshi

Copyright ( 2011 Nico Rublack et al. This is an open access article distributed under the Creative Commons Attribution License, which permits unrestricted use, distribution, and reproduction in any medium, provided the original work is properly cited.

\begin{abstract}
Nowadays, RNA synthesis has become an essential tool not only in the field of molecular biology and medicine, but also in areas like molecular diagnostics and material sciences. Beyond synthetic RNAs for antisense, aptamer, ribozyme, and siRNA technologies, oligoribonucleotides carrying site-specific modifications for structure and function studies are needed. This often requires labeling of the RNA with a suitable spectroscopic reporter group. Herein, we describe the synthesis of functionalized monomer building blocks that upon incorporation in RNA allow for selective reaction with a specific reporter or functional entity. In particular, we report on the synthesis of $5^{\prime}$-O-dimethoxytrityl-2'-O-tert-butyldimethylsilyl protected 3'-O-phosphoramidites of nucleosides that carry amino linkers of different lengths and flexibility at the heterocyclic base, their incorporation in a variety of RNAs, and postsynthetic conjugation with fluorescent dyes and nitroxide spin labels. Further, we show the synthesis of a flavine mononucleotide-N-hydroxy-succinimidyl ester and its conjugation to amino functionalized RNA.
\end{abstract}

\section{Introduction}

Over the past two decades, RNA synthesis has become a very active field. Synthetic RNAs are required for a large number of applications. Antisense oligonucleotides, ribozymes, aptamers, and siRNAs are required for medicinal diagnostic and therapy as well as for a wide variety of biochemistry and molecular biology studies $[1,2]$. Furthermore, aptamers and reporter ribozymes are designed and applied in environmental diagnostics [3]. A number of other disciplines make use of synthetic oligoribonucleotides, for example, the field of material science, where novel materials from nanoparticle oligonucleotide conjugates are generated [4]. In parallel, RNA synthesis has developed to a degree that allows the synthesis of RNA oligonucleotides of any desired sequence from microgram to multigram scale. In addition to $2^{\prime}-O-$ TBDMS chemistry, which may be considered as the standard procedure for RNA preparation, novel strategies mainly focussing on different $2^{\prime}-O$-protecting groups such as $2^{\prime}-O$ TOM, $2^{\prime}-O$-ACE or $2^{\prime}-O$-TC are available for laboratory use applying the specific monomer building blocks, or have been commercialized for custom RNA synthesis $[5,6]$.
Research in our laboratory is devoted to the chemistry and biochemistry of RNA with a strong focus on RNA aptamers and ribozymes. Therefore, we synthesize natural and modified RNA strands required for the design of functional RNAs that we want to investigate. Furthermore, we also prepare RNA molecules carrying site-specific modifications such as fluorescent dyes or other reporter groups to be used for studies into RNA structure. A number of monomer building blocks for the synthesis of modified RNA are commercially available. For example, amino linkers for $5^{\prime}$ - and/or $3^{\prime}$-terminal labeling can be obtained ready for use in RNA assembly (Figure 1). Furthermore, $5^{\prime}-\mathrm{O}$ DMT-2'-O-TBDMS protected $3^{\prime}$ - $O$-phosphoramidites of $2^{\prime}$ aminouridine (3) and 4-thiouridine (4) (Figure 1) are available and after incorporation in RNA can be used for the specific attachment of desired molecular entities.

However, monomer building blocks of the purine nucleosides with functionalities suitable for postsynthetic conjugation are completely missing, and also in the pyrimidine series, the few existing derivatives of uridine do not offer much variety. Therefore, a currently very active part of our 

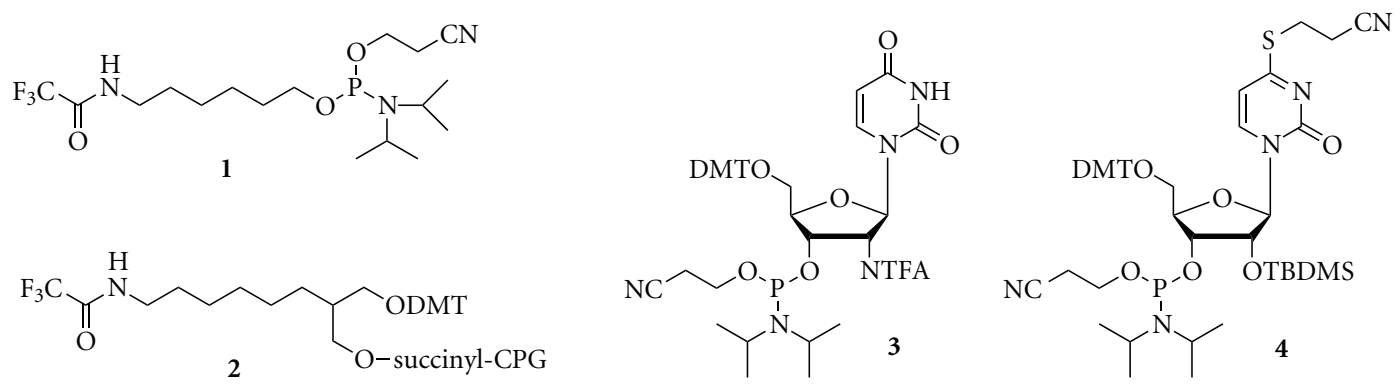

FIgURE 1: Structures of the commercially available building blocks used in our RNA functionalization studies.

research is focussed on the synthesis of $5^{\prime}-O-D M T-2^{\prime}-O$ TBDMS protected $3^{\prime}$-O-phosphoramidites of nucleosides that carry functionalized linkers of different lengths and flexibility at the heterocyclic base, in particular at C5 of the pyrimidines as well as at $\mathrm{C} 8$ and $\mathrm{C} 2$ of the purines (Figure 2). Moreover, we currently work at the synthesis of modified nucleosides as they appear in tRNA as well as of isotope enriched nucleosides and their incorporation in specific RNA sequences (which will be reported elsewhere).

Herein, we focus on the synthesis of amino-modified monomers, their incorporation into RNA, and the postsynthetic labeling with fluorescent dyes. Furthermore, we report on strategies for preparation of specifically spin labeled RNAs for EPR studies, and on the preparation of a flavinmononucleotide (FMN) derivative that is postsynthetically attached to an amino-modified hairpin ribozyme derivative. The modified RNAs described herein are used in collaboration with spectroscopists for structural analysis of functional RNAs, such as RNA thermometers [7] and RNA four-way junctions [8] or riboswitches [9], or in RNA engineering projects like the design of an FMN-dependent aptazyme [10].

\section{Materials and Methods}

2.1. General Information. All reactions were carried out in dry solvents under argon atmosphere. All solvents and reagents were purchased from commercial sources and used as supplied unless otherwise stated. The solvents used in Pd coupling reactions were freed from oxygen. All products were visualized on TLC plates (aluminium sheets coated with silica gel $60 \mathrm{~F} 254,0.2 \mathrm{~nm}$ thickness) at $254 \mathrm{~nm}$ ultraviolet light. The linker molecules L1, L2, and L3 (Figure 3) were synthesized according to the literature: the alkinyl linker L1 was synthesized according to Cruickshank and Stockwell [11], and alkenyl linkers were synthesized as described by Dey and Sheppard [12] and McKeen et al. [13]. All modified phosphoramidites were freshly prepared prior to use in RNA synthesis. Progress of reaction was monitored by TLC (hexane/ethyl acetate $1: 1$ containing 1\% $\mathrm{NEt}_{3}$ ). Phosphoramidites were coevaporated several times with dry DCM and kept under vacuum over $\mathrm{P}_{2} \mathrm{O}_{5}$ in a desiccator overnight. A $0.1 \mathrm{M}$ solution of the modified phosphoramidite in anhydous acetonitril was freshly prepared right before use in solid-phase RNA synthesis.
2.2. MALDI-TOF Analysis. For nucleoside derivatives: 1$2 \mathrm{mg}$ sample was dissolved in $100 \mu \mathrm{L}$ methanol or water. $1.5 \mu \mathrm{L}$ of the sample solution and $1.5-3.0 \mu \mathrm{L}$ of the matrix solution (30-40 mg 3-hydroxypicolinic acid (3-HPA) in $500 \mu \mathrm{L} \mathrm{MeCN} / \mathrm{H}_{2} \mathrm{O} 1: 1$, vigorously mixed for $30 \mathrm{~s}$ ) were mixed, and $1-2 \mu \mathrm{L}$ of that mixture was loaded on a MALDIplate, dried, and allowed to crystallize. The sample was analyzed on a Bruker microflex mass spectrometer. The program was set as reflective positive mode with 40-50 shoots/measurement. The laser intensity was adjusted such that the intensity of the desired signals was about 1000 .

For RNA: RNA samples were desalted by gel filtration on Sephadex G25 fine (GE Healthcare). After desalination, samples were dissolved in autoclaved micropore water to a concentration of about $100-500 \mathrm{pmol} / \mu \mathrm{L} .1 \mu \mathrm{L}$ of this RNA solution was mixed with $1-2 \mu \mathrm{L}$ of matrix solution (30-40 mg 3-hydroxypicolinic acid (3-HPA) in $500 \mu \mathrm{L} \mathrm{MeCN} / \mathrm{H}_{2} \mathrm{O}$ $1: 1$, vigorously mixed for $30 \mathrm{~s}$ ) and treated with cationexchange beads (Dowex $50 \mathrm{WX} 8, \mathrm{NH}_{4}{ }^{+}$-form, 100-200 mesh, ServaFeinbiochemica). Therefore, $4-7 \mu \mathrm{L}$ suspension of the beads in autoclaved micropore water was pipetted in a $250 \mu \mathrm{L}$ tube, and water was removed, followed by addition of the sample and matrix solutions. The mixture was left at rt for 10 min then loaded on the MALDI-plate and dried on air. The sample was measured using the linear negative (or positive) mode with 40-50 shoots/measurement. In addition to the main peak $[\mathrm{M}-1]^{-}$(negative mode) or $[\mathrm{M}+1]^{+}$ (positive mode), occasionally the signals corresponding to $[\mathrm{M}-2] / 2$ were observed.

2.3. Synthesis of Amino-Modified Monomer Building Blocks. Amino linker-modified uridine derivatives were synthesized as described [14]. The detailed synthesis of linker-modified adenosine derivatives with focus on the problem of double bond isomerization will be reported elsewhere (H. Nguyen, B. Appel, and S. Müller, manuscript in preparation).

2.4. 8-(3-Trifluoroacetamidoprop-1-ynyl)guanosine 16. 8Bromoguanosine-hydrate 15 (98\%) (1448.4 mg. $4.0 \mathrm{mmol}$ ) was dissolved in dry DMF $(32 \mathrm{~mL})$. Traces of dissolved oxygen in the solution were removed by iterative cycles of reduced pressure and passing in argon (3 times). Then, $\mathrm{Pd}\left(\mathrm{Ph}_{3} \mathrm{P}\right)_{4}$ (464 mg, $0.4 \mathrm{mmol}, 0.1$ eq.) was added. The solution was again kept under vacuum and then saturated with argon. DIPEA $(816 \mu \mathrm{L}, 4.8 \mathrm{mmol}, 1.2$ eq., freshly 
<smiles>[R]n1cc(/C=C/CNC(=O)C(F)(F)F)c(=O)[nH]c1=O</smiles><smiles>[R]n1cc(/C=C/CNC(=O)C(S)NC(=O)C(F)(F)F)c(=O)[nH]c1=O</smiles><smiles>[R]n1cc(C#CCNC(=O)C(F)(F)F)c(=O)[nH]c1=O</smiles><smiles>[R]n1c(C/C=C/NC(=O)C(F)(F)F)nc2c([NH3+])ncnc21</smiles><smiles>[R]n1c(C/C=C/NCCNC(C)=O)nc2c([NH2+])ncnc21</smiles><smiles>[R]n1c(C#CCNC(=O)C(F)(F)F)nc2c([NH2+])ncnc21</smiles><smiles>[R]n1cnc2c([NH2+])nc(/C=C/CNC(=O)C(F)(F)F)nc21</smiles><smiles>[R]n1cnc2c([NH3+])nc(/C=C/CNC(=O)C(C)NC(=O)C(F)(F)F)nc21</smiles><smiles>[R]n1cnc2c([NH2+])nc(C#CCNC(=O)C(F)(F)F)nc21</smiles><smiles>[R]n1c(C#CCNC(=O)C(F)(F)F)nc2c(=O)[nH]c(N)nc21</smiles>

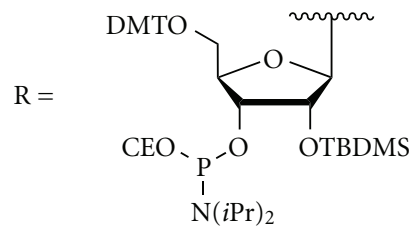

FIGURE 2: Amino-modified monomer building blocks used for RNA synthesis and functionalization.<smiles>C=CCNC(=O)C(F)(F)F</smiles>

L1<smiles>C=CCNC(=O)C(C)NC(=O)C(F)(F)F</smiles>

L2<smiles>C#CCNC(=O)C(F)(F)F</smiles>

L3

FIGURE 3: Amino linkers used for preparation of amino-modified nucleosides.

distilled over $\mathrm{CaH}_{2}$ ) was added via a syringe, followed by the addition of $N$-propynyltrifluoroacetamide L3 (1208 mg, $8.0 \mathrm{mmol}, 2.0$ eq.) and $\mathrm{CuI}$ (152 mg, $0.8 \mathrm{mmol}, 0.2$ eq.). The mixture was stirred at $40^{\circ} \mathrm{C}$ for 20 hours. The solvent was then removed to give a brown viscous oil which was dissolved in DCM/MeOH 1:1 (v/v) and filtered to remove the precipitate. The solid residue was purified by silica gel column chromatography (DCM/MeOH 90:10 to 84:16 $(\mathrm{v} / \mathrm{v}))$ to give a pale yellow solid. Yield: $2765.4 \mathrm{mg}(6.4 \mathrm{mmol}$, $80 \%) . \mathrm{R}_{\mathrm{f}}\left(\mathrm{SiO}_{2} ; \mathrm{DCM} / \mathrm{MeOH} 60: 40(\mathrm{v} / \mathrm{v})\right): 0.80 .{ }^{1} \mathrm{H}$ NMR $\left(300 \mathrm{MHz}, \mathrm{DMSO}-\mathrm{d}_{6}\right): \delta(\mathrm{ppm})=3.50\left(1 \mathrm{H}, \mathrm{m}, \mathrm{H}-5^{\prime}\right), 3.64$ $\left(1 \mathrm{H}, \mathrm{m}, \mathrm{H}-5^{\prime \prime}\right), 3.84\left(1 \mathrm{H}, \mathrm{m}, \mathrm{H}-4^{\prime}\right), 4.12\left(1 \mathrm{H}, \mathrm{m}, \mathrm{H}-3^{\prime}\right)$, $4.36\left(2 \mathrm{H}, \mathrm{d}, \mathrm{J} 5.4, \mathrm{CH}_{2}\right), 4.88\left(2 \mathrm{H}, \mathrm{m}, \mathrm{H}-2^{\prime}\right.$ and $\left.\mathrm{OH}\right), 5.04$ ( $1 \mathrm{H}, \mathrm{d}, \mathrm{J} 4.8, \mathrm{OH}), 5.40$ (1 H, d, J 6.0, OH), 5.76 (1 H, d, J 6.3, H-1' $), 6.57$ (2 H, br s, $\left.\mathrm{NH}_{2}\right), 10.20(1 \mathrm{H}, \mathrm{t}, \mathrm{J}$ 5.4, NH), 10.90 ( $1 \mathrm{H}$, br s, NH). ${ }^{13} \mathrm{C}$ NMR (300 MHz, DMSO-d 6 ): $\delta(\mathrm{ppm})=29.40,62.06,70.47,70.85,72.75,85.77,88.38$,
89.12, (110.03, 113.84, 117.65 and 121.47, q, J 288.02, $\left.\mathrm{CF}_{3}\right)$, $117.24,129.04,150.90,154.12$, (155.54, 156.03, 156.51 and 157.00, q, J 36.76, $\left.(\mathrm{C}=\mathrm{O}) \mathrm{CF}_{3}\right)$, 156.24. MALDI-TOF: $\mathrm{C}_{15} \mathrm{H}_{15} \mathrm{~F}_{3} \mathrm{~N}_{6} \mathrm{O}_{6}$, calculated 432.10, found $432.82[\mathrm{M}+\mathrm{H}]^{+}$.

2.5. N-2-Isobutyryl-8-(3-trifluoroacetamidoprop-1-ynyl)guanosine 17. 8-(3-Trifluoroacetamido-prop-1-ynyl)guanosine $16(216.5 \mathrm{mg}, 0.50 \mathrm{mmol})$ was coevaporated with anhydrous pyridine $(3 \times 4 \mathrm{~mL})$, and then dissolved in anhydrous pyridine $(2 \mathrm{~mL})$. The resulting solution was protected from moisture (drying tube), purged with argon and placed on ice. To the ice cold solution, TMS-Cl ( $0.55 \mathrm{~mL}, 4.1 \mathrm{mmol}, 8.2$ eq.) was added dropwise via a syringe. The ice bath was then removed and the mixture was stirred for 2 hours. The solution was cooled on ice and isobutyric anhydride $(0.13 \mathrm{~mL}$, $1.1 \mathrm{mmol}, 2.2$ eq.) was added dropwise via a syringe and the 
Journal of Nucleic Acids

ice bath was removed. After stirring for another 2 hours at room temperature, the reaction was placed again on ice and ice cold water $(20 \mathrm{~mL})$ was slowly added, followed after 15 minutes by concentrated ammonia solution $(1.5 \mathrm{~mL})$ to get a final $2.5 \mathrm{M}$ concentration of ammonia. The mixture was kept on ice for 30 minutes, and then evaporated to dryness. The residue was coevaporated with toluene $(3 \times 5 \mathrm{~mL})$ to remove traces of water, resuspended in $\mathrm{MeOH}$ and filtered to remove the precipitate. The filtrate was then concentrated, dissolved in a small amount of $\mathrm{MeOH}$, absorbed on silica gel and purified by column chromatography (DCM/MeOH $95: 5$ to $91: 9$ $(\mathrm{v} / \mathrm{v})$ ) to give $\mathrm{N}$-2-isobutyryl-8-(3trifluoroacetamidoprop-1ynyl)guanosine as a yellow solid. Yield: $183.3 \mathrm{mg}(0.37 \mathrm{mmol}$; $73 \%) . \mathrm{R}_{\mathrm{f}}\left(\mathrm{SiO}_{2} ; \mathrm{DCM} / \mathrm{MeOH} 80: 20(\mathrm{v} / \mathrm{v})\right): 0.63,{ }^{1} \mathrm{H} \mathrm{NMR}$ $\left(300 \mathrm{MHz}, \mathrm{DMSO}-\mathrm{d}_{6}\right): \delta(\mathrm{ppm})=1.13(6 \mathrm{H}, \mathrm{d}, \mathrm{J} 6.9$, $\left.\mathrm{CH}\left(\mathrm{CH}_{3}\right)_{2}\right), 2.79\left(1 \mathrm{H}\right.$, sept, J 6.9, $\left.\mathrm{CH}\left(\mathrm{CH}_{3}\right)_{2}\right), 3.53(1 \mathrm{H}, \mathrm{m}$, H-5'), 3.68 ( $\left.1 \mathrm{H}, \mathrm{m}, \mathrm{H}-5^{\prime \prime}\right), 3.84$ ( $\left.1 \mathrm{H}, \mathrm{m}, \mathrm{H}-4^{\prime}\right), 4.17$ (1 H, br s, H-3' $), 4.40\left(2 \mathrm{H}, \mathrm{s}, \mathrm{CH}_{2}\right), 4.81(1 \mathrm{H}$, br s, H-2' $), 4.91(1 \mathrm{H}$, br s, OH), 5.09 ( $1 \mathrm{H}$, br s, OH), $5.50(1 \mathrm{H}$, br s, OH), 5.86 (1 H, d, J 6.0, H-1' $), 10.21$ (1 H, br s, NH), 11.62 (1 H, br s, $\mathrm{NH}), 12.16$ ( $1 \mathrm{H}$, br s, NH). MALDI-TOF: $\mathrm{C}_{19} \mathrm{H}_{21} \mathrm{~F}_{3} \mathrm{~N}_{6} \mathrm{O}_{7}$, calculated 502.14 , found $502.84[\mathrm{M}+\mathrm{H}]^{+}$.

2.6. 5'-O-(4,4'-Dimethoxytrityl)-N-6-isobutyryl-8-(3-trifluoroacetamidoprop1ynyl)guanosine 18. N-2-Isobutyryl-8(3-trifluoroacetamidoprop-1-ynyl)guanosine 17 (1174.4 mg, $2.4 \mathrm{mmol})$ was coevaporated with anhydrous pyridine $(3 \times$ $3 \mathrm{~mL})$ and dissolved in anhydrous pyridine $(10.0 \mathrm{~mL})$. DMT-Cl (1219.8 mg, $3.6 \mathrm{mmol}, 1.5 \mathrm{eq}$.) was dissolved in anhydrous pyridine $(3.0 \mathrm{~mL})$ and added dropwise to the ice cold solution of the nucleoside over 2.5 hours. After 6 hours at ice cold temperature, TLC analysis (DCM/ $\mathrm{MeOH}$ 95:5(v/v)) showed that the starting material was completely consumed. Methanol $(1.0 \mathrm{~mL})$ was added to quench the unreacted DMT-Cl, and after 10 minutes, the solution was concentrated to dryness in vacuo. The residue was dissolved in DCM $(100 \mathrm{~mL})$, washed with a $5 \%$ aqueous solution of $\mathrm{NaHCO}_{3}(2 \times 20 \mathrm{~mL})$ and water $(2 \times 20 \mathrm{~mL})$. The organic layer was dried over $\mathrm{Na}_{2} \mathrm{SO}_{4}$ and concentrated to give a yellow gum which was purified by column chromatography (DCM/MeOH $97: 3$ to $95: 5(\mathrm{v} / \mathrm{v})$ containing $1 \%$ triethylamine) to give a pale yellow foam. Yield: $1671.6 \mathrm{mg}(2.08 \mathrm{mmol}, 87 \%) . \mathrm{R}_{\mathrm{f}}(\mathrm{DCM} / \mathrm{MeOH} 90: 10$ $(\mathrm{v} / \mathrm{v})): 0.44 .{ }^{1} \mathrm{H}$ NMR $\left(300 \mathrm{MHz}, \mathrm{DMSO}-\mathrm{d}_{6}\right): \delta(\mathrm{ppm})=1.11$ $\left(6 \mathrm{H}, 2 \times \mathrm{d}, \mathrm{J} 6.9\right.$ and 6.6, $\left.\mathrm{CH}\left(\mathrm{CH}_{3}\right)_{2}\right), 2.72(1 \mathrm{H}$, sept, J 6.9, $\left.\mathrm{CH}\left(\mathrm{CH}_{3}\right)_{2}\right), 3.11$ and $3.45\left(2 \mathrm{H}, \mathrm{m}, \mathrm{H}-5^{\prime}\right.$ and $\left.\mathrm{H}-5^{\prime \prime}\right), 3.69$ and $3.71\left(6 \mathrm{H}, 2 \times \mathrm{s}, 2 \times \mathrm{OCH}_{3}\right), 4.04\left(1 \mathrm{H}, \mathrm{m}, \mathrm{H}-4^{\prime}\right), 4.31$ $\left(3 \mathrm{H}\right.$, br s, H-3' and $\left.\mathrm{CH}_{2}\right), 4.91\left(1 \mathrm{H}, \mathrm{m}, \mathrm{H}-2^{\prime}\right), 5.04(1 \mathrm{H}$, br s, OH), $5.61\left(1 \mathrm{H}\right.$, br s, OH), $5.94\left(1 \mathrm{H}, \mathrm{d}, \mathrm{J} 4.5, \mathrm{H}-1^{\prime}\right)$, $6.73(4 \mathrm{H}, 2 \times \mathrm{d}, \mathrm{J} 8.7$ and 9.0, aromatic), $7.23(9 \mathrm{H}, \mathrm{m}$, aromatic), $10.85(3 \mathrm{H}$, br s, $3 \times \mathrm{NH}) .{ }^{13} \mathrm{C} \mathrm{NMR}(300 \mathrm{MHz}$, DMSO- $\left.\mathrm{d}_{6}\right): \delta(\mathrm{ppm})=18.71,18.94,29.33,34.80,54.86$, 54.91, 64.72, 70.49, 71.36, 72.06, 84.21, 85.21, 89.91, 90.49, (110.02, 113.82, 117.65 and 121.47, q, J 288.5, $\left.\mathrm{CF}_{3}\right), 112.73$, $112.82,120.83,126.45,127.47,127.78,129.64,129.80$, $131.52,135.58,144.87,148.24,154.33$, (155.55, 156.05, 156.53 and 157.03, q, J 37.0, $\left.(\mathrm{C}=\mathrm{O}) \mathrm{CF}_{3}\right), 157.88,157.95$, 180.09. MALDI-TOF: $\mathrm{C}_{40} \mathrm{H}_{39} \mathrm{~F}_{3} \mathrm{~N}_{6} \mathrm{O}_{9}$, calculated 804.27, found $805.24[\mathrm{M}+\mathrm{H}]^{+}$.
2.7. $5^{\prime}-O-\left(4,4^{\prime}\right.$-Dimethoxytrityl)-2' -(tert-butyldimethylsilyl)$\mathrm{N}$-2-isobutyryl-8-(3-trifluoroacetamidoprop-1-ynyl)guanosine 19. $5^{\prime}$-O-(4,4' -Dimethoxytrityl)-N-2-isobutyryl-8-(3-trifluoroacetamidoprop-1-ynyl)guanosine $\mathbf{1 8}$ (1623 mg, $2.02 \mathrm{mmol}$ ) was coevaporated with anhydrous pyridine $(2 \mathrm{~mL} \times 2)$, dry DCM $(2 \times 5 \mathrm{~mL})$, kept under vacuum overnight, and then dissolved in anhydrous THF $(20 \mathrm{~mL})$. Anhydrous pyridine $(606 \mu \mathrm{L}, 7.47 \mathrm{mmol}, 3.7$ eq. $)$ and $\mathrm{AgNO}_{3}$ (505 mg, $3.0 \mathrm{mmol}$, 1.5 eq.) were added. The reaction mixture was stirred for 15 minutes to give a white emulsion, and TBDMS-Cl (528 mg, $3.43 \mathrm{mmol}, 1.7$ eq.) was added. The reaction was protected from moisture and stirred at room temperature until TLC $\left(\mathrm{SiO}_{2}\right.$, hexane/ethyl acetate $1: 1(\mathrm{v} / \mathrm{v}))$ showed no starting material left $(8.5$ hours). The reaction mixture was diluted with ethyl acetate $(50 \mathrm{~mL})$, filtered to remove the precipitate and washed with a saturated solution of $\mathrm{NaHCO}_{3}(2 \times 20 \mathrm{~mL})$. The organic layer was dried over $\mathrm{Na}_{2} \mathrm{SO}_{4}$ and concentrated under reduced pressure to give a white gum which was then purified by silica gel column chromatography (hexane/ethyl acetate $85: 15$ to $40: 60(\mathrm{v} / \mathrm{v}))$ to give a pale yellow foam. Yield: $482.3 \mathrm{mg}(0.53 \mathrm{mmol}, 26 \%) . \mathrm{R}_{\mathrm{f}}\left(\mathrm{SiO}_{2}\right.$; hexane/ethyl acetate $1: 1(\mathrm{v} / \mathrm{v})$ containing $4 \% \mathrm{MeOH}): 0.41 .{ }^{1} \mathrm{H} \mathrm{NMR}$ $\left(300 \mathrm{MHz}, \mathrm{DMSO}-\mathrm{d}_{6}\right): \delta(\mathrm{ppm})=-0.14$ and $-0.02(6 \mathrm{H}$, $\left.2 \times \mathrm{s}, \mathrm{Si}\left(\mathrm{CH}_{3}\right)_{2}\right), 0.76\left(9 \mathrm{H}, \mathrm{s}, \mathrm{SiC}\left(\mathrm{CH}_{3}\right)_{3}\right), 1.09(6 \mathrm{H}, 2 \times$ d, J 6.6 and 6.9, $\left.\mathrm{CH}\left(\mathrm{CH}_{3}\right)_{2}\right), 2.70$ (1 H, sept, J 6.6 and 6.9, $\left.\mathrm{CH}\left(\mathrm{CH}_{3}\right)_{2}\right), 3.19\left(1 \mathrm{H}, \mathrm{m}, \mathrm{H}-5^{\prime}\right), 3.51\left(1 \mathrm{H}, \mathrm{m}, \mathrm{H}-5^{\prime \prime}\right), 3.67$ and $3.69\left(6 \mathrm{H}, 2 \times \mathrm{s}, 2 \times \mathrm{OCH}_{3}\right), 4.09\left(1 \mathrm{H}, \mathrm{m}, \mathrm{H}-4^{\prime}\right), 4.20$ $\left(1 \mathrm{H}\right.$, br m, H-3'), 4.38 ( $2 \mathrm{H}$, br d, J 5.1, $\left.\mathrm{CH}_{2}\right), 4.79(1 \mathrm{H}$, m, H-2' $), 5.95(1 \mathrm{H}, \mathrm{d}, \mathrm{J}$ 4.8, H-1' $), 6.75(4 \mathrm{H}, 2 \times \mathrm{d}, \mathrm{J}$ 8.7, aromatic), 7.27 (9 H, m, aromatic), $10.16(1 \mathrm{H}, \mathrm{t}, \mathrm{J} 5.1$ and 5.4, NH), 11.38 (1 H, br s, NH), 12.14 ( $1 \mathrm{H}$, br s, NH). 13C NMR (300 MHz, DMSO-d 6 ): $\delta(\mathrm{ppm})=-5.40,-4.91$, $17.81,18.63,18.88,25.47,29.24,34.77,54.89,54.93,64.49$, $70.16,71.95,73.74,84.26,85.30,90.66,(109.97,113.79$, 117.61 and $\left.121.43, \mathrm{q}, \mathrm{J} 288.40, \mathrm{CF}_{3}\right), 112.82,112.87,126.51$, $127.55,127.76,129.70,129.78,135.50,135.58,144.86$, $148.52,154.10,(155.54,156.03,156.52$ and $157.01, q, J$ 37.0, $\left.(\mathrm{C}=\mathrm{O}) \mathrm{CF}_{3}\right), 157.93,157.98,180.07$. MALDI-TOF: $\mathrm{C}_{46} \mathrm{H}_{53} \mathrm{~F}_{3} \mathrm{~N}_{6} \mathrm{O}_{9} \mathrm{Si}$, calculated 918.36, found $919.19[\mathrm{M}+\mathrm{H}]^{+}$.

2.8. $5^{\prime}-O-\left(4,4^{\prime}\right.$-Dimethoxytrityl)-2' -(tert-butyldimethylsilyl)N-2-isobutyryl-8-(3-trifluoroacetamidoprop-1-ynyl)guanosinephosphoramidite 14. 5'-O-(4,4'-Dimethoxytrityl)-2' (tert-butyldimethylsilyl)-N-2-isobutyryl-8-(3-trifluoroacetamidoprop-1-ynyl)guanosine 19 (67.96 mg, $0.11 \mathrm{mmol})$ was coevaporated with anhydrous pyridine $(2 \times 5 \mathrm{~mL})$, dry DCM $(2 \times 5 \mathrm{~mL})$, kept under vacuum overnight, and then dissolved in anhydrous DCM $(2 \mathrm{~mL})$. To the resulting solution, DIPEA $(75 \mu \mathrm{L}, 0.44 \mathrm{mmol}, 4$ eq. $)$ was added, followed by 2-cyanoethyl- $N, N$-diisopropylchlorophosphoramidite $(37 \mu \mathrm{L}, 0.16 \mathrm{mmol}, 1.5 \mathrm{eq})$. The solution was stirred at room temperature. The reaction was followed by TLC (EtOAc: hexane 1:1 containing 1\% TEA). After 2.5 hours, the reaction was stopped and washed with a saturated solution of $\mathrm{NaHCO}_{3}(10 \mathrm{~mL})$. The organic layer was dried over $\mathrm{Na}_{2} \mathrm{SO}_{4}$ and filtered, and the solvent was removed under reduced pressure. The residue was purified by silica gel column chromatography. The column was 
packed with DCM/TEA $(98: 2)$, the residue was dissolved in 1-2 $\mathrm{mL}$ DCM/TEA $(98: 2)$, and the column was loaded. After $30 \mathrm{~mL}$ of DCM/TEA $(98: 2)$, the solvent was changed to DCM/TEA/MeCN $(49: 1: 50,50 \mathrm{~mL})$. The fractions containing the desired product were collected, and the solvent was removed under reduced pressure. The product was lyophilized overnight. ${ }^{31} \mathrm{P}-\mathrm{NMR}\left(300 \mathrm{MHz}, \mathrm{DMSO}-\mathrm{d}_{6}\right)$, two diastereomers: $\delta(\mathrm{ppm})=148.98,149.71$.

2.9. RNA Synthesis. Oligoribonucleotides were synthesized by the phosphoramidite method on a Pharmacia Gene Assembler Plus, at $1 \mu \mathrm{mol}$ scale as described elsewhere [15]. Standard PAC-phosphoramidites as well as CPG supports were obtained from ChemGenes or Link Technologies. BMT (emp Biotech) was used as activator [16]. The modified nucleoside phosphoramidites were coevaporated three times with dry dichloromethane, kept under vacuum for 2 hours to remove traces of solvents, stored in vacuum over $\mathrm{P}_{2} \mathrm{O}_{5}$ overnight, and used in oligo synthesis as $0.1-0.15 \mathrm{M}$ solution in acetonitrile. The solutions of phosphoramidites, BMT, and $\mathrm{MeCN}$ were kept over molecular sieve $0.3 \mathrm{~nm}$. The coupling time for all natural and modified building blocks was $5 \mathrm{~min}$. All syntheses were carried out "trityl-off". The obtained RNA was cleaved from the support and deprotected using $\mathrm{NH}_{3}$ (30\%) and ethanolic methylamine in a $1: 1$ mixture and TEAx3HF as described [17] and purified by gel electrophoresis using 10\% denaturing polyacrylamide gels. Elution was carried out using $0.5 \mathrm{M} \mathrm{LiOAc}$ followed by EtOH precipitation. Oligonucleotides were analyzed by PAGE and MALDI MS.

2.10. Postsynthetic Labeling of Oligoribonucleotides with Alexa488, Cy5 and ATTO647N. 5 to $10 \mathrm{nmol}$ aminomodified RNA were dissolved in $15-25 \mu \mathrm{L} 0.1 \mathrm{M}$ Borax buffer, at $\mathrm{pH} 9.4$ for Alexa488 coupling reactions, and at $\mathrm{pH} 8.7$ for $\mathrm{Cy} 5$ and ATTO647N coupling reactions. The mixture was added to a solution of $100 \mu \mathrm{g}$ dye in $5 \mu \mathrm{L}$ DMF (the solution of the dye in DMF was freshly prepared just before use). The coupling reaction was carried out at room temperature overnight in the dark. Excess of dye was removed via gel filtration (Sephadex G25 fine, GE Healthcare). The Alexa488 and Cy5 labeled RNAs were purified by denaturing PAGE. The sample was denatured at $90^{\circ} \mathrm{C}$ for 3 minutes, immediately subjected onto a $15 \%$ polyacrylamide gel $(200 \times 150 \times 1.5 \mathrm{~mm})$, and electrophoresis was run at $400 \mathrm{~V}$ for 5.5 hours in the dark. The band corresponding to the labeled RNA was cleaved out; the RNA was eluted with $0.5 \mathrm{M}$ lithium acetate and precipitated from ethanol at $-20^{\circ} \mathrm{C}$ (yield $15-37 \%$ for Alexa $488,26-54 \%$ for Cy5). The ATTO647N labeled RNA was purified by reverse-phase HPLC. The RNA was solved in $1 \mathrm{~mL}$ water and filtered through a $0.45 \mu \mathrm{L}$ filter before subjecting onto the column. Column EC 250/4 Nucleodur 100-5 C18 ec (MachereyNagel), flow rate $0.5 \mathrm{~mL} / \mathrm{min}$, Buffer A $0.1 \mathrm{M}$ TEAAc $(\mathrm{pH}$ 7), $5 \% \mathrm{MeCN}$, Buffer B 0.1 M TEAAc (pH 7), 70\% MeCN, Gradient 0\% B for $5 \mathrm{~min}, 10-55 \%$ B in $76 \mathrm{~min}, 55-100 \%$ B in 19 minutes (yield $40-50 \%$ ).

\subsection{Hybridization of Single-Stranded RNAs for Structural Studies on RNA Thermometer}

Condition A. For the hybridization of unlabeled singlestranded oligonucleotides, D1L3 (300 pmol) and A1L3 (300 pmol) were dissolved in $50 \mathrm{mM}$ Tris buffer, $\mathrm{pH} 7.4$ in the presence of $10 \mathrm{mM} \mathrm{MgCl}_{2}$ in a total volume of $100 \mu \mathrm{L}$. The solution was then well mixed, incubated at $78^{\circ} \mathrm{C}$ for 3 minutes, centrifuged to collect the vapor on the cap of the eppendorf tube, wrapped in aluminium film, and slowly cooled down to room temperature. The hybrid was analyzed by $15 \%$ native polyacrylamide gel.

Condition B. Alexa Fluor 488-labeled D1L3 (25 pmol) and Cy5-labeled A1L3 (25 pmol), were dissolved in $20 \mathrm{mM}$ $\mathrm{KH}_{2} \mathrm{PO}_{4}-\mathrm{K}_{2} \mathrm{HPO}_{4}$ buffer, $\mathrm{pH} 6.5$ in the presence of $10 \mathrm{mM}$ $\mathrm{MgCl}_{2}$ and $100 \mathrm{mM} \mathrm{KCl}$ in a total volume of $50 \mu \mathrm{L}$. The components were then mixed, centrifuged and incubated at $78^{\circ} \mathrm{C}$ for 3 minutes. The mixture was slowly cooled down to room temperature in aluminium film. The hybridization was checked by $15 \%$ native polyacrylamide gel.

2.12. $5^{\prime}$-O-(4,4'-Dimethoxytrityl)riboflavin 21. To a suspension of riboflavin $20(1.5 \mathrm{~g}, 4 \mathrm{mmol})$ in dry pyridine TEA ( $2 \mathrm{~mL}, 14.4 \mathrm{mmol}$ ), DMAP (24 mg, $0.2 \mathrm{mmol}$ ), and 4, $4^{\prime}-$ dimethoxytritylchloride $(1.7 \mathrm{~g}, 5.2 \mathrm{mmol}$ ) were added under argon. After 4 hours of stirring at room temperature in the dark, the reaction was quenched with dry methanol $(5 \mathrm{~mL})$. The solvent was evaporated under reduced pressure. The residue was dissolved in DCM $(100 \mathrm{~mL})$ and filtered. The clear yellow filtrate was dried with $\mathrm{Na}_{2} \mathrm{SO}_{4}$ and the solvent was removed. Purification of the crude product by column chromatography with $\mathrm{DCM} / \mathrm{MeOH}(98: 2)$ gave the tritylated product 21 as an orange solid. Yield: $1.4 \mathrm{~g}$ $(2.1 \mathrm{mmol}, 53 \%) .{ }^{1} \mathrm{H}$ NMR $\left(300 \mathrm{MHz}, \mathrm{DMSO}-\mathrm{d}_{6}\right): \delta(\mathrm{ppm})$ $=2.39\left(\mathrm{~s}, 3 \mathrm{H}, \mathrm{CH}_{3}\right), 2.41\left(\mathrm{~s}, 3 \mathrm{H}, \mathrm{CH}_{3}\right), 3.20-3.17(\mathrm{~m}, 2 \mathrm{H})$, 3.72 and $3.73\left(2 \times \mathrm{s}, 2 \times 3 \mathrm{H}, 2 \times \mathrm{OCH}_{3}\right), 3.92($ br s, $1 \mathrm{H})$, $4.23($ br s, $1 \mathrm{H}), 4.62(\mathrm{~m} 1 \mathrm{H}), 4.98(\mathrm{~m}, 1 \mathrm{H}), 6.85(\mathrm{~m}, 4 \mathrm{H}$, DMT), 7.46-7.16 (m, 9 H, DMT), $7.83(\mathrm{~s}, 1 \mathrm{H}), 7.90(\mathrm{~s}, 1 \mathrm{H})$, 11.34 (s, $1 \mathrm{H}, \mathrm{NH})$. ESI-MS: $\mathrm{C}_{38} \mathrm{H}_{38} \mathrm{~N}_{4} \mathrm{O}_{8}$, calculated 678.27, found $677.26[\mathrm{M}-\mathrm{H}]^{-}$.

2.13. $2^{\prime}, 3^{\prime}, 4^{\prime}$-Tri-O-acetyl-5'-O-(4,4'-dimethoxytrityl) riboflavin 22. $5^{\prime}-O-\left(4,4^{\prime}\right.$-Dimethoxytrityl)-riboflavin 21 (1.4 g, $2.06 \mathrm{mmol})$ in dry pyridine $(200 \mathrm{~mL})$ was cooled in an ice bath under argon atmosphere. After dropwise addition of acetic anhydride $(7.6 \mathrm{~mL}, 80 \mathrm{mmol})$, the solution was stirred in the dark at room temperature overnight. Then, methanol $(5 \mathrm{~mL})$ was added, and the solvent was evaporated. Column chromatography with $\mathrm{DCM} / \mathrm{MeOH}(98: 2)$ gave the title compound 22 as orange foam. Yield: $1.5 \mathrm{~g}(1.86 \mathrm{mmol}, 90 \%)$. ${ }^{1} \mathrm{H}$ NMR $(300 \mathrm{MHz}$, DMSO-d 6$): \delta(\mathrm{ppm})=1.49(\mathrm{~s}, 3 \mathrm{H}$, acetyl- $\left.\mathrm{CH}_{3}\right), 2.02\left(\mathrm{~s}, 3 \mathrm{H}\right.$, acetyl- $\left.\mathrm{CH}_{3}\right), 2.27(\mathrm{~s}, 3 \mathrm{H}$, acetyl$\left.\mathrm{CH}_{3}\right), 2.39\left(\mathrm{~s}, 3 \mathrm{H}, \mathrm{CH}_{3}\right), 2.46\left(\mathrm{~s}, 3 \mathrm{H}, \mathrm{CH}_{3}\right), 3.12-3.05(\mathrm{~m}$, $1 \mathrm{H}), 3.29-3.22(\mathrm{~m}, 1 \mathrm{H}), 3.73\left(2 \times \mathrm{s}, 2 \times 3 \mathrm{H}, 2 \times \mathrm{OCH}_{3}\right)$, 5.16-4.79 (br m, $2 \mathrm{H}), 5.24(\mathrm{~m}, 1 \mathrm{H}), 5.54(\mathrm{~m}, 2 \mathrm{H}), 6.88$ (m, $4 \mathrm{H}, \mathrm{DMT}), 6.37-7.20$ (m, 9 H, DMT), $7.64(\mathrm{~s}, 1 \mathrm{H}), 7.89$ (s, $1 \mathrm{H}), 11.40(\mathrm{~s}, 1 \mathrm{H}, \mathrm{NH})$, ESI-MS: $\mathrm{C}_{44} \mathrm{H}_{44} \mathrm{~N}_{4} \mathrm{O}_{11}$, calculated 804.30, found $803.29[\mathrm{M}-\mathrm{H}]^{-}$. 
2.14. $2^{\prime}, 3^{\prime}, 4^{\prime}-$ Tri-O-acetylriboflavin 23. $2^{\prime}, 3^{\prime}, 4^{\prime}$ - Tri-O-

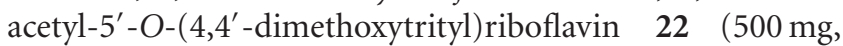
$0.6 \mathrm{mmol}$ ) was dissolved in $20 \mathrm{~mL}$ nitromethane. To this solution, anhydrous $\mathrm{ZnBr}_{2}(1.25 \mathrm{~g}, 5.6 \mathrm{mmol})$ was added. After 2 minutes, the reaction was quenched by addition of ammonium acetate $(50 \mathrm{~mL}, 1 \mathrm{M}$ in water). DCM $(50 \mathrm{~mL})$ were added, the organic layer was separated and washed with brine $(2 \times 20 \mathrm{~mL})$, followed by evaporation under reduced pressure. The crude product was extracted several times with ice cold diethyl ether to remove residual DMT. In this way, compound 23 (250 mg, $0.5 \mathrm{mmol}$ ) were obtained as a yellow solid. The product was used for the next reaction without further purification. MALDI-TOF: $\mathrm{C}_{23} \mathrm{H}_{26} \mathrm{~N}_{4} \mathrm{O}_{9}$, calculated 502.17, found $503.23[\mathrm{M}+\mathrm{H}]^{+}$.

2.15. 3-(Tetraethylene glycol)propionic Acid tert-Butyl Ester 25. Tetraethylene glycol $24(38.8 \mathrm{~g}, 200 \mathrm{mmol})$ was dissolved in dry THF $(80 \mathrm{~mL})$. Under argon atmosphere, sodium $(0.2 \mathrm{~g}, 8.7 \mathrm{mmol})$ was added. After all of the sodium had dissolved, tert-butylacrylate $(7.7 \mathrm{~g}, 60 \mathrm{mmol})$ were added and the mixture was stirred at room temperature for 23 hours. The slightly yellow solution was neutralized with $1 \mathrm{M} \mathrm{HCl}$ and the solvents were evaporated under reduced pressure. The residue was redissolved in brine $(80 \mathrm{~mL})$ and extracted with ethyl acetate $(3 \times 50 \mathrm{~mL})$. The combined organic layers were washed with water and dried with sodium sulfate. After evaporation of the solvents, the oil was subjected to column chromatography on silica gel (DCM/MeOH 98:2) to give 25 as colorless oil. Yield: $6.65 \mathrm{~g}(20.6 \mathrm{mmol}, 34 \%)$. ${ }^{1} \mathrm{H} \mathrm{NMR}\left(300 \mathrm{MHz}, \mathrm{CDCl}_{3}\right): \delta(\mathrm{ppm})=1.45(\mathrm{~s}, 9 \mathrm{H}$, tertbutyl), $2.50\left(\mathrm{t}, 2 \mathrm{H}, \mathrm{CH}_{2}\right.$-COO-tert-Bu), 3.74-3.60 (m, $18 \mathrm{H}$, $\mathrm{OCH}_{2} \mathrm{CH}_{2} \mathrm{O}$ ). MALDI-TOF: $\mathrm{C}_{15} \mathrm{H}_{30} \mathrm{O}_{7}$, calculated 322.20, found $345.16[\mathrm{M}+\mathrm{Na}]^{+}$.

2.16. 3-(Tetraethylene glycol)propionic Acid tert-Butyl Ester Phosphoramidite 26. 3-(Tetraethylene glycol)propionic acid tert-butyl ester $25(1 \mathrm{~g}, 3.1 \mathrm{mmol})$ was coevaporated three times with dichloromethane and then dissolved in $25 \mathrm{~mL}$ DCM under argon. To this solution, freshly distilled DIPEA $(2.5 \mathrm{~mL})$ and 2-cyanoethyl- $N, N$-diisopropropylchlorophosphoramidite $(0.85 \mathrm{ml}, 3.6 \mathrm{mmol})$ were added. After 1.5 hours, the reaction was stopped by addition of $1 \mathrm{~mL}$ methanol. The mixture was diluted with ethylacetate $(20 \mathrm{~mL})$ and TEA $(1.5 \mathrm{~mL})$ and washed with a saturated solution of $\mathrm{NaHCO}_{3}(25 \mathrm{~mL})$ and brine $(25 \mathrm{~mL})$. The organic layer was dried with $\mathrm{Na}_{2} \mathrm{SO}_{4}$, and the solvents were removed under reduced pressure. The crude product was coevaporated three times with dry DCM and stored overnight in an evacuated desiccator with calcium chloride. According to TLC analysis, the phosphoramidite was sufficiently pure to be used for the next reaction without further purification. ${ }^{31} \mathrm{P}$ NMR (300 $\left.\mathrm{MHz}, \mathrm{CDCl}_{3}\right)$, two diastereomers: $\delta(\mathrm{ppm})=148.45,149.37$.

2.17. 5'-O-(3-(Tetraethylene glycol)propionic Acid tert-Butyl Ester- $\beta$-cyanoethylphosphoryl)-2', $3^{\prime}, 4^{\prime}$-tri-O-Acetylriboflavin 27. All starting materials were coevaporated separately with dry DCM. The riboflavine derivative 23 (100 mg, $0.2 \mathrm{mmol}$ ) was dissolved in dry $\mathrm{MeCN}(15 \mathrm{~mL})$. To this solution, phosphoramidite 26 ( $136 \mathrm{mg}, 0.26 \mathrm{mmol})$ in $2 \mathrm{~mL}$ dry MeCN and BMT (192 mg, $1 \mathrm{mmol}$ ) in $3 \mathrm{~mL} \mathrm{MeCN}$ were added. The reaction mixture was stirred for 1 hour at room temperature. A solution of $0.2 \mathrm{M}$ iodine in a mixture of THF/pyridine/ $\mathrm{H}_{2} \mathrm{O}(2: 1: 1)$ was added. After ten minutes, sodium bisulfite ( $5 \%$ in water) was added until the brown color had vanished. The mixture was diluted with DCM $(40 \mathrm{~mL})$. The organic layer was washed with sodium bicarbonate and brine and finally dried over sodium sulfate. The solvents were evaporated under reduced pressure. The residue was purified by reversed phase HPLC. Column VP125 Nucleosil 120-10 C18 ec (Macherey-Nagel), flow rate $0.5 \mathrm{~mL} / \mathrm{min}$, Eluent A $10 \% \mathrm{MeOH}$, Eluent B $70 \%$ $\mathrm{MeOH}$, Gradient $0-70 \% \mathrm{~B}$ in $5 \mathrm{CV}, 70-100 \% \mathrm{~B}$ in $3 \mathrm{CV}$, $100 \%$ B 3 CV. Yield: $59.5 \mathrm{mg}(63 \mathrm{nmol}, 32 \%) .{ }^{1} \mathrm{H}$ NMR $\left(300 \mathrm{MHz}, \mathrm{CDCl}_{3}\right)$, two diastereomers: $\delta(\mathrm{ppm})=1.44(\mathrm{~s}$, $9 \mathrm{H}$, tert-butyl), $1.79(\mathrm{~s}, 3 \mathrm{H}), 2.21(2 \times \mathrm{s}, 3 \mathrm{H}), 2.35$ and 2.33 $(2 \times \mathrm{s}, 3 \mathrm{H}), 2.44(\mathrm{~s}, 3 \mathrm{H}), 2.50\left(\mathrm{t}, 2 \mathrm{H}, \mathrm{CH}_{2}\right.$-COO-tert-Bu), $2.57(\mathrm{~s}, 3 \mathrm{H}), 2.81\left(\mathrm{~m}, 2 \mathrm{H}, \mathrm{CH}_{2}-\mathrm{CN}\right), 3.74-3.60(\mathrm{~m}, 18 \mathrm{H}$, $\left.\mathrm{OCH}_{2} \mathrm{CH}_{2} \mathrm{O}\right), 4.40-4.21\left(\mathrm{~m}, 6 \mathrm{H}, \mathrm{P}-\mathrm{O}-\mathrm{CH}_{2}\right), \quad 5.33-4.89$ (br, $2 \mathrm{H}), 5.41(\mathrm{~m}, 1 \mathrm{H}), 5.50(\mathrm{~m}, 1 \mathrm{H}), 5.65(\mathrm{~m}, 1 \mathrm{H}), 7.60$ and $7.59(2 \times \mathrm{s}, 1 \mathrm{H}), 8.02(\mathrm{~s}, 1 \mathrm{H}), 8.80$ and $8.76(2 \times \mathrm{s}$, $1 \mathrm{H}, \mathrm{NH})$. MALDI-TOF: $\mathrm{C}_{41} \mathrm{H}_{58} \mathrm{~N}_{5} \mathrm{O}_{18} \mathrm{P}$, calculated 939.35, found $962.62[\mathrm{M}+\mathrm{Na}]^{+}$.

2.18. 5'-O-(3-(Tetraethylene glycol)propionic Acid- $\beta$-cyanoethylphosphoryl)-2', 3', 4'-tri-O-Acetylriboflavin 28. The fully protected coupling compound $27(25 \mathrm{mg}, 26.6 \mathrm{nmol})$ was treated with $1 \mathrm{~mL}$ DCM/TFA $(1: 1)$ for 1 hour at room temperature. Subsequently, the solvents were evaporated under reduced pressure, and the residue was purified by reversed phase HPLC to give the free acid as an orange solid. Column VP125 Nucleosil 120-10 C18 ec (Macherey-Nagel), flow rate $0.5 \mathrm{~mL} / \mathrm{min}$, Eluent A 10\% $\mathrm{MeOH}$, Eluent B $70 \%$ $\mathrm{MeOH}$, Gradient $0-70 \% \mathrm{~B}$ in $5 \mathrm{CV}, 70-100 \% \mathrm{~B}$ in $3 \mathrm{CV}$, $100 \%$ B 3 CV. Yield $18.8 \mathrm{mg}(21.3 \mathrm{nmol}, 80 \%) .{ }^{1} \mathrm{H}$ NMR $\left(300 \mathrm{MHz}, \mathrm{DMSO}-\mathrm{d}_{6}\right)$, two diastereomers: $\delta(\mathrm{ppm})=1.61$ $(\mathrm{s}, 3 \mathrm{H}), 2.20(\mathrm{~s}, 3 \mathrm{H}), 2.25(\mathrm{~s}, 3 \mathrm{H}), 2.41(\mathrm{~s}, 3 \mathrm{H}), 2.43(\mathrm{t}$, $\left.2 \mathrm{H}, \mathrm{CH}_{2}-\mathrm{COOH}\right), 2.51(\mathrm{~s}, 3 \mathrm{H}), 2.93\left(\mathrm{~m}, 2 \mathrm{H}, \mathrm{CH}_{2}-\mathrm{CN}\right)$, 3.63-3.48 (m, $\left.18 \mathrm{H}, \mathrm{OCH}_{2} \mathrm{CH}_{2} \mathrm{O}\right), 4.41-4.10(\mathrm{~m}, 6 \mathrm{H}, \mathrm{P}-$ O-CH $\left.{ }_{2}\right), 4.83(\mathrm{~d}, 1 \mathrm{H}), 5.18-5.00(\mathrm{br}, 1 \mathrm{H}), 5.32(\mathrm{~m}, 1 \mathrm{H})$, $5.48(\mathrm{~m}, 2 \mathrm{H}), 7.73(\mathrm{~s}, 1 \mathrm{H}), 7.90(\mathrm{~s}, 1 \mathrm{H}), 11.40(\mathrm{~s}, 1 \mathrm{H}$, NH). MALDI-TOF: $\mathrm{C}_{37} \mathrm{H}_{50} \mathrm{~N}_{5} \mathrm{O}_{18} \mathrm{P}$, calculated 883.29, found $906.43[\mathrm{M}+\mathrm{Na}]^{+}$.

2.19. 5'-O-(3-(Tetraethylene glycol)propionic Acid Phosphoryl)riboflavin 29. In $4 \mathrm{~mL}$ of a $30 \%$ ammonia solution in methanol, the riboflavin derivative $\mathbf{2 8}(15 \mathrm{mg}, 17 \mathrm{nmol})$ was dissolved and stirred at room temperature. After $30 \mathrm{~min}$, MALDI analysis showed complete conversion to product. The solvents were evaporated, and the solid was taken up in $1 \mathrm{~mL}$ deionized water and subjected onto a short DOWEX column $\left(\mathrm{H}^{+}\right.$form, $\left.4 \times 1.5 \mathrm{~cm}\right)$. The product was eluted with water and dried in vacuo. Yield: $11 \mathrm{mg}(15.6 \mathrm{nmol}, 92 \%)$. ${ }^{1} \mathrm{H}$ NMR: $\left(600 \mathrm{MHz}, \mathrm{DMSO}-\mathrm{d}_{6}\right): \delta(\mathrm{ppm})=2.40(\mathrm{~s}, 3 \mathrm{H})$, $2.43\left(\mathrm{t}, 2 \mathrm{H}, \mathrm{CH}_{2}-\mathrm{COOH}\right), 2.49(\mathrm{~s}, 3 \mathrm{H}), 3.61-3.47(\mathrm{~m}, 16 \mathrm{H}$, $\left.\mathrm{OCH}_{2} \mathrm{CH}_{2} \mathrm{O}\right), 3.64(\mathrm{~m}, 1 \mathrm{H}), 3.86(\mathrm{~m}, 1 \mathrm{H}), 3.90(\mathrm{~m}, 1 \mathrm{H})$, $4.00(\mathrm{~m}, 2 \mathrm{H}), 4.11(\mathrm{~m}, 1 \mathrm{H}), 4.24(\mathrm{~m}, 1 \mathrm{H}), 4.65(\mathrm{~d}, 1 \mathrm{H})$, 
$4.89(\mathrm{~m}, 1 \mathrm{H}), 7.90(\mathrm{~s}, 2 \mathrm{H}), 11.35$ (s, $1 \mathrm{H}, \mathrm{NH})$. MALDI-TOF: $\mathrm{C}_{28} \mathrm{H}_{41} \mathrm{~N}_{4} \mathrm{O}_{15} \mathrm{P}$, calculated 704.23, found 705.32 $[\mathrm{M}+\mathrm{H}]^{+}$.

2.20. Introduction of Spin Labels to RNA Containing 4Thiouridine. The modified nucleotide 4-thiouridine was incorporated at preselected positions of RNAs, to be used for postsynthetic spin labeling with 1-oxyl- 2,2,5,5tetramethylpyrroline-3-methyl)methane-thiosulfonate or $N$-(1-oxyl-2,2,5,5-tetramethyl-3-pyrrolidinyl)iodoacetamide. RNA samples were incubated for 2 hours at room temperature with a 200-fold excess of dithiothreitol (DTT) in $50 \mu \mathrm{L}$ of $100 \mathrm{mM}$ sodium phosphate puffer $(\mathrm{pH} 8.0)$. The reducing agent was removed by demineralization using centrifugal filters, followed by lyophilization of the RNA. Spin labeling was carried out overnight by incubation of a $100 \mu \mathrm{M}$ solution of the respective RNA in $90 \mathrm{mM}$ sodium phosphate buffer $(90 \% \mathrm{v} / \mathrm{v})(\mathrm{pH} 8.0)$ and DMF $(10 \%$ $\mathrm{v} / \mathrm{v})$ with a 10-fold excess of 1-oxyl-2,2,5,5-tetramethylpyrroline-3-methyl)methanethiosulfonate or $\mathrm{N}$-(1-oxyl2,2,5,5-tetramethyl-3-pyrrolidinyl)iodoacetamide, respectively. Unbound nitroxide reagent was removed by demineralization and lyophilization as described above. The spin label efficiency ranged from $10 \%$ to $100 \%$.

2.21. Introduction of Spin Labels to RNA Containing $2^{\prime}$-Aminouridine. RNAs were synthesized with $2^{\prime}$-aminouridine at predefined positions and subsequently spin labeled.

2.21.1. Reaction with (1-Oxyl-2,2,5,5-tetramethylpyrrolin3-carboxylat)-N-Hydroxysuccinimidyl Ester. A solution of the RNA in $80 \mathrm{mM}$ borax buffer ( $\mathrm{pH} 8.5)(90 \% \mathrm{v} / \mathrm{v})$, DMF $(10 \% \mathrm{v} / \mathrm{v})$ containing $10 \mathrm{mM} \mathrm{NaCl}$ was incubated for 5 hours at $37^{\circ} \mathrm{C}$ with a 500 -fold excess of (1-oxyl-2,2,5,5tetramethylpyrrolin-3-carboxylat)- $N$-hydroxysuccinimidyl ester. Side products and unreacted reagents were extracted with $300 \mu \mathrm{L}$ chloroform at room temperature followed by precipitation of the labeled RNA from ethanol. The pellet was resolved in water, the solution was demineralized using centrifugal filters, and finally, the sample was lyophilized. Yields were between $70 \%$ and $80 \%$.

2.21.2. Reaction with 4-Isocyanato-2,6-tetramethylpiperidyl$\mathrm{N}$-oxid. A solution of the RNA in $50 \mathrm{mM}$ borax buffer $(\mathrm{pH}$ $8.5)(50 \% \mathrm{v} / \mathrm{v})$, DMF $(20 \% \mathrm{v} / \mathrm{v})$ and formamide $(30 \% \mathrm{v} / \mathrm{v})$ was cooled to $-8^{\circ} \mathrm{C}$ and incubated for 2 hours with a 15 -fold excess of 4-isocyanato-2,6-tetramethylpiperidyl- $\mathrm{N}$ oxid. Side products and unreacted reagent were extracted with $300 \mu \mathrm{L}$ chloroform at room temperature followed by precipitation of the labeled RNA from ethanol. The pellet was resolved in water, the solution was demineralized using centrifugal filters, and finally, the sample was lyophilized. Yields were between $75 \%$ and $100 \%$.

\section{Results and Discussion}

3.1. Synthesis of Natural and Modified RNA with Commercially Available Building Blocks. The coupling reaction of RNA phosphoramidites is less facile than that of DNA phosphoramidite building blocks; hence, the coupling yields normally are slightly poorer. Thus, chemical synthesis of RNA is limited by the length of the oligomers. Up to now, we, therefore, preferred to synthesize nonmodified RNA molecules which are longer than 70 bases by in vitro transcription techniques as described [17]. Shorter nonmodified and modified RNAs in our laboratory are prepared by solid phase synthesis. Our procedure is based on 2'O-tert-butyldimethylsilyl (TBDMS) nucleoside protection and involves sequential couplings of $\beta$-cyanoethyl- $\left(N, N^{\prime}-\right.$ diisopropyl)phosphoramidites of $5^{\prime}$-O-dimethoxytrityl-2'$O$-TBDMS nucleosides essentially by the method as described [17]. For assembly of the oligoribonucleotides, we predominantly use CPG or polystyrene beads to which the first ribonucleoside derivative is attached via its $3^{\prime}-\mathrm{OH}$ group as a succinate linkage. The standard synthesis is on the micromole scale, and for coupling of phosphoramidites, we use 5benzylmercaptotetrazole activation [16] and coupling times of $5 \mathrm{~min}$. Under these conditions, the yields in couplings are usually in the $99 \%$ range. We have synthesized a variety of amino- and 4-thiouridine-modified RNAs (Tables 1, 2, and 3) that were postsynthetically functionalized with fluorescent dyes, spin labels, or flavine mononucleotide as described below.

The $5^{\prime}$ - and $3^{\prime}$-amino modifiers, as well as 4-thiouridine were introduced during RNA solid phase synthesis using commercially available building blocks (Figure 1). While for the $5^{\prime}$-amino modifier, the standard coupling conditions were used, 4-thiouridine was introduced by two consecutive couplings of 5 minutes each using fresh amidite solution. After chain assembly was completed, cleavage from the solid support and removal of base-protecting groups were accomplished by treatment with aqueous $\mathrm{NH}_{3}(30 \%)$ and ethanolic methylamine in a $1: 1$ mixture for $2 \mathrm{~h}$ at room temperature. We found this protocol advantageous over the usage of $\mathrm{NH}_{3} / \mathrm{MeOH}$, as we had applied previously [18]. Finally, 2'-O-TBDMS groups were removed by fluoride ion treatment. While $1 \mathrm{M}$ tetrabutylammonium fluoride was conventionally used for this purpose, we prefer the use of triethylamine trihydrofluoride first suggested by Gasparutto et al. [19]. In combination with polar aprotic solvents and at elevated temperatures, this reagent offers advantages in speed and reliability [20]. Therefore, we use triethylamine trihydrofluoride/DMF $(3: 1)$ at $55^{\circ} \mathrm{C}$ for 1.5 hours for efficient removal of the $2^{\prime}$-O-TBDMS groups. Following deprotection, oligonucleotides were desalted by precipitation with $n$-butanol and purified by electrophoresis on denaturing polyacrylamide gels or by HPLC. The yields of oligonucleotides shown in Tables 1-3 were in the range of 1 to $400 \mathrm{nmol}$ after purification.

\subsection{Synthesis of Amino-Modified RNA Building Blocks} and Incorporation in RNA. Within a collaborative research project, the three-dimensional architecture of structured RNAs, for example, RNA thermometers [7] or RNA four-way junctions [8], is investigated by quantitative fluorescence resonance energy transfer (FRET) measurements. For absolute distance measurements by FRET, the microenvironment of the probe attached to the sample is very important. However, 
TABLE 1: Sequences of synthesized linker-modified RNA oligonucleotides. The bold letters (U/A) mark the position of the modification (see Figure 2).

\begin{tabular}{|c|c|c|c|c|}
\hline Name & Length & Sequence & Mod. & Dye \\
\hline A1L1 & $25 \mathrm{nts}$ & UGG CAA GCU CGC AGU CGG CAC CGC C & 5 & Cy5 \\
\hline A1L2 & $25 \mathrm{nts}$ & UGG CAA GCU CGC AGU CGG CAC CGC C & 6 & $\begin{array}{l}\text { Cy5, ATTO } \\
647 \mathrm{~N}\end{array}$ \\
\hline A1L3 & $25 \mathrm{nts}$ & UGG CAA GCU CGC AGU CGG CAC CGC C & 7 & Cy5 \\
\hline A2L1 & $25 \mathrm{nts}$ & UGG CAA GCU CGC AGU CGG CAC CGC C & 5 & Cy5 \\
\hline A2L2 & $25 \mathrm{nts}$ & UGG CAA GCU CGC AGU CGG CAC CGC C & 6 & $\begin{array}{l}\text { Cy5, ATTO } \\
647 \mathrm{~N}\end{array}$ \\
\hline A2L3 & $25 \mathrm{nts}$ & UGG CAA GCU CGC AGU CGG CAC CGC C & 7 & Cy5 \\
\hline D1L1 & $25 \mathrm{nts}$ & GGC GGU GCC GAC UGC GAG CUU GCC A & 5 & Alexa 488 \\
\hline D1L2 & $25 \mathrm{nts}$ & GGC GGU GCC GAC UGC GAG CUU GCC A & 6 & Alexa 488 \\
\hline D1L3 & $25 \mathrm{nts}$ & GGC GGU GCC GAC UGC GAG CUU GCC A & 7 & Alexa 488 \\
\hline L2-TEST & $8 \mathrm{nts}$ & GGA AUU CC & 6 & - \\
\hline 2-L3-A & $8 \mathrm{nts}$ & GGA AUU CC & 7 & ATTO $647 \mathrm{~N}$ \\
\hline 8-L1-A & $8 \mathrm{nts}$ & UUA GUA CU & 8 & - \\
\hline 2-L3-A & $8 \mathrm{nts}$ & GGA AAU CC & 10 & ATTO $647 \mathrm{~N}$ \\
\hline RNA-25 & $32 \mathrm{nts}$ & CCC CAC GUC AAG GCG UGG UGG CCG AAG GUC GG & 6 & Cy5 \\
\hline RNA-26 & $32 \mathrm{nts}$ & CCG ACC UUC GGC CAC CUG ACA GUC CUG UGG GG & 6 & Alexa 488 \\
\hline $4 \mathrm{U}$-Ther. & $60 \mathrm{nts}$ & $\begin{array}{l}\text { GGC GGU GCC GAC UGC GAG CUU GCC AUG UUG AAC UUU } \\
\text { UGA AUA GUG AUU CAG GAG GUU AAU }\end{array}$ & 6 & Alexa 488 \\
\hline 4U-Ther. & $60 \mathrm{nts}$ & $\begin{array}{l}\text { GGC GGU GCC GAC UGC GAG CUU GCC AUG UUG AAC UUU } \\
\text { UGA AUA GUG AUU CAG GAG GUU AAU }\end{array}$ & 6 & Alexa 488 \\
\hline $4 \mathrm{U}$-Ther. & $60 \mathrm{nts}$ & $\begin{array}{l}\text { GGC GGU GCC GAC UGC GAG CUU GCC AUG UUG AAC UUU } \\
\text { UGA AUA GUG AUU CAG GAG GUU AAU }\end{array}$ & 6 & Alexa 488 \\
\hline 4U-Ther. & $60 \mathrm{nts}$ & $\begin{array}{l}\text { GGC GGU GCC GAC UGC GAG CUU GCC AUG UUG AAC UUU } \\
\text { UGA AUA GUG AUU CAG GAG GUU AAU }\end{array}$ & 6 & Alexa 488 \\
\hline 4U-Ther. & $60 \mathrm{nts}$ & $\begin{array}{l}\text { GGC GGU GCC GAC UGC GAG CUU GCC AUG UUG AAC UUU } \\
\text { UGA AUA GUG AUU CAG GAG GUU AAU }\end{array}$ & 6 & Alexa 488 \\
\hline
\end{tabular}

the commercial availability of building blocks for internal labeling of RNA is rare. Therefore, often molecules with a deoxy sugar moiety at the position of the internal label are applied for structural studies. In order to provide a set of nucleotides that upon incorporation in RNA can be used for RNA functionalization at a desired internal site, we started an effort to synthesize various ribonucleoside phosphoramidite building blocks with amino linkers of different lengths and flexibility attached to the heterocyclic base. We choose one short (L1) and one long (L2) rather flexible linker (Figure 3) coupled to the nucleobases by Heck chemistry $[12,13]$ and a short alkynyl linker (L3) (Figure 3) that was introduced by Sonogashira coupling [11].

In a first row of experiments, we have attached the three different linkers at C5 of uridine by palladium catalyzed cross-coupling reactions as described [14] (see 5, 6, and 7 in Figure 2).

Furthermore, adenosine derivatives with alkenyl linkers L1 and L2 at C8 or C2 were prepared under analogous conditions as used for uridine derivatives $\mathbf{5}$ and $\mathbf{6}$. However, a striking difference was the formation of double bond isomers in the Heck coupling reaction. Even though this phenomenon is well known in the field of palladium catalyzed crosscoupling reactions, we were surprised observing a strong influence of the nature of the catalysts on formation of either isomer. Thorough investigation of a variety of catalysts and reaction conditions allowed us to tune reaction towards one of the two possible isomers by the choice of the catalysts $(\mathrm{H}$. Nguyen, B. Appel, and S. Müller, manuscript in preparation). The specific amino-modified adenosine derivatives shown in Figure 2 were obtained with $\mathrm{Na}_{2}\left[\mathrm{PdCl}_{4}\right](\mathbf{8}, \mathbf{9}$, and 12) or with the catalyst palladacycle (11) [21].

The phosphoramidite building blocks 7, 10, 13, and 14 carrying the propargylamino linker (Figure 2) were prepared by Pd-catalyzed Sonogashira cross-coupling. Due to the milder conditions compared with Heck chemistry, successful Sonogashira reaction could be carried out at fully protected nucleosides. Protection is not essential; however, we found introduction of sugar and base protecting groups prior to the cross-coupling reaction advantageous, since the overall yield in this case was higher. The synthesis starts with the introduction of the DMT- and TBDMS protecting group via standard procedures $[22,23]$. Then, the propargylamino linker L3 was coupled to the nucleobase by Sonogashira 
TABLE 2: Sequences of spin labelled RNAs. The bold U marks the position of 4-thiouridine, and the underlined U the position of 2 '-aminouridine.

\begin{tabular}{|c|c|c|c|}
\hline Name & Sequence & Spin label & Yield (\%) \\
\hline \multirow[t]{2}{*}{ VW1 } & $\begin{array}{l}\text { GGG CUA AAA CAU ACC AGA UUUCGA UCU GGA GAG GUG AAG AAU ACG } \\
\text { ACC ACC UAG CUC }\end{array}$ & TPM-MTS & 25 \\
\hline & & TMP-IAA & 23 \\
\hline \multirow[t]{2}{*}{ VW2 } & $\begin{array}{l}\text { GGG CUA AAA CAU ACC AGA UUUCGA UCU GGA GAG GUG AAG AAU ACG } \\
\text { ACC ACC UAG CUC }\end{array}$ & TPM-MTS & 10 \\
\hline & & TMP-IAA & 63 \\
\hline \multirow[t]{2}{*}{ VW3 } & $\begin{array}{l}\text { GGG CUA AAA CAU ACC AGA UUUCGA UCU GGA GAG GUG AAG AAU ACG } \\
\text { ACC ACC UAG CUC }\end{array}$ & TPM-MTS & 20 \\
\hline & & TMP-IAA & 80 \\
\hline VW4 & $\begin{array}{l}\text { GGG CUA AAA CAU ACC AGA UUUCGA UCU GGA GAG GUG AAG AAU ACG } \\
\text { ACC ACC UAG CUC }\end{array}$ & TPM-MTS & 77 \\
\hline VW5 & $\begin{array}{l}\text { GGG CUA AAA CAU ACC AGA UUUCGA UCU GGA GAG GUG AAG AAU ACG } \\
\text { ACC ACC UAG CUC }\end{array}$ & TPM-MTS & 25 \\
\hline VW6 & $\begin{array}{l}\text { GGG CUA AAA CAU ACC AGA UUUCGA UCU GGA GAG GUG AAG AAU ACG } \\
\text { ACC ACC UAG CUC }\end{array}$ & TPM-MTS & 100 \\
\hline VW7 & $\begin{array}{l}\text { GGG CUA AAA CAU ACC AGA UUUCGA UCU GGA GAG GUG AAG AAU ACG } \\
\text { ACC ACC UAG CUC }\end{array}$ & TPM-MTS & 61 \\
\hline VW8 & $\begin{array}{l}\text { GGG CUA AAA CAU ACC AGA UUUCGA UCU GGA GAG GUG AAG AAU ACG } \\
\text { ACC ACC UAG CUC }\end{array}$ & TPM-MTS & 13 \\
\hline VW9 & $\begin{array}{l}\text { GGG CUA AAA CAU ACC AGA UUU CGA UCU GGA GAG GUG AAG AAU } \\
\text { ACG ACC ACCUAG CUC }\end{array}$ & TPM-MTS & 45 \\
\hline VW10 & $\begin{array}{l}\text { GGG CUA AAA CAU ACC AGA UUUCGA UCU GGA GAG GUG AAG AAU ACG } \\
\text { ACC ACC UAG CUC }\end{array}$ & TPM-MTS & 89 \\
\hline VW11 & $\begin{array}{l}\text { GGG CUA AAA CAU ACC AGA UUUCGA UCU GGA GAG GUG AAG AAU ACG } \\
\text { ACC ACC UAG CUC }\end{array}$ & TPM-MTS & 89 \\
\hline VW12 & $\begin{array}{l}\text { GGG CUA AAA CAU ACC AGA UUUCGA UCU GGA GAG GUG AAG AAU ACG } \\
\text { ACC ACC UAG CUC }\end{array}$ & TPM-MTS & 10 \\
\hline \multirow[t]{2}{*}{ HPAS11 } & ACC AGA GAA ACA GCC U $\underline{U} A$ GGA UAU GCU GG & TMC-NHS & 81 \\
\hline & & TEMPO-NCO & 83 \\
\hline \multirow[t]{2}{*}{ HPAS12 } & CCA GCA GAA GGA CG $\underline{U}$ CGU AUA UUA CCU GGU & TMC-NHS & 80 \\
\hline & & TEMPO-NCO & 77 \\
\hline \multirow[t]{2}{*}{ HPAS13 } & ACC AGA GAA ACA ACC U U GG GC & TMC-NHS & 82 \\
\hline & & TEMPO-NCO & 97 \\
\hline \multirow[t]{2}{*}{ HPAS14 } & GGC AAG GUC GUA UAU UAC CUG GU & TMC-NHS & 85 \\
\hline & & TEMPO-NCO & 75 \\
\hline \multirow[t]{2}{*}{ HPAS15 } & ACC AGA GAA ACA GAC U $\underline{U G}$ GC & TMC-NHS & 72 \\
\hline & & TEMPO-NCO & 100 \\
\hline \multirow[t]{2}{*}{ HPAS16 } & 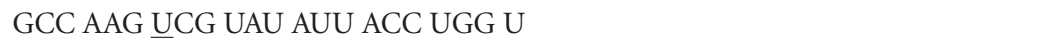 & TMC-NHS & 80 \\
\hline & & TEMPO-NCO & 82 \\
\hline
\end{tabular}

reaction, and finally, the phosphoramidite was prepared as described above for the C5-propargylamino uridine derivative.

Adenosine derivatives with the propargyl amino linker at C8 and C2 were prepared following the same route. However, as an additional step, the exocyclic amino group of the base was protected prior to introduction of the other protecting groups and of the linker unit.
The propargylamino linker was also attached to $\mathrm{C} 8$ of guanosine starting from 8-bromoguanosine. The exocyclic amino group was protected as an amide using isobutyric anhydride. The DMT and the TBDMS group were introduced according to standard methods $[22,23]$ as described above, and finally, the phosphoramidite was prepared with 4 eq. of ethyl diisopropyl amine and 1.5 eq. of 2-cyanoethylN,N-diisopropylchlorophosphoramidite (Figure 4). 
TABLE 3: Sequences of two-stranded or three-stranded amino modified aptazymes. APU: 5-(3-Aminoprop-1-enyl)uridine. AMU: 2'-aminouridine.

\begin{tabular}{|c|c|c|c|}
\hline Name & Length & Sequence & Mod. X \\
\hline HPAT2-L12 & $72 \mathrm{nts}$ & $\begin{array}{l}\text { AAA GAG AGA AGU GAA CCA GAG AAA CAG CCU UAG GAU AXG CUU CGG } \\
\text { CAG AAG GAC GUC GUA UAU UAC CUG GUA }\end{array}$ & APU \\
\hline HPAT2-L14 & $72 \mathrm{nts}$ & $\begin{array}{l}\text { AAA GAG AGA AGU GAA CCA GAG AAA CAG CCU UAG GAX AUG CUU CGG } \\
\text { CAG AAG GAC GUC GUA UAU UAC CUG GUA }\end{array}$ & APU \\
\hline HPAT2-U12 & $72 \mathrm{nts}$ & $\begin{array}{l}\text { AAA GAG AGA AGU GAA CCA GAG AAA CAG CCU UAG GAU AXG CUU CGG } \\
\text { CAG AAG GAC GUC GUA UAU UAC CUG GUA }\end{array}$ & AMU \\
\hline HPAT2-U14 & $72 \mathrm{nts}$ & $\begin{array}{l}\text { AAA GAG AGA AGU GAA CCA GAG AAA CAG CCU UAG GAX AUG CUU CGG } \\
\text { CAG AAG GAC GUC GUA UAU UAC CUG GUA }\end{array}$ & AMU \\
\hline HPAT1-AAM & $43 \mathrm{nts}$ & AAA GAG AGA AGU GAA CCA GAG AAA CAG CCU UAG GAX AUG CUG G & AMU \\
\hline HPAT1-AHI & 43 nts & AAA GAG AGA AGU GAA CCA GAG AAA CAG CCU UAG GAX AUG CUG G & APU \\
\hline HPAT1-BAM & 43 nts & AAA GAG AGA AGU GAA CCA GAG AAA CAG CCU UAG GAU AXG CUG G & AMU \\
\hline HPAT1-BHI & $43 \mathrm{nts}$ & AAA GAG AGA AGU GAA CCA GAG AAA CAG CCU UAG GAU AXG CUG G & APU \\
\hline HPAT2 & $31 \mathrm{nts}$ & CCA GCA GAA GGA CGU CGU AUA UUA CCU GGU A & - \\
\hline
\end{tabular}

15<smiles></smiles>

$\stackrel{\text { (i) }}{\longrightarrow}$ $\stackrel{\text { (iii) }}{\longleftarrow}$

$\stackrel{(\mathrm{v})}{\longrightarrow}$<smiles></smiles>
(ii)<smiles></smiles>
$\downarrow$ (iv)

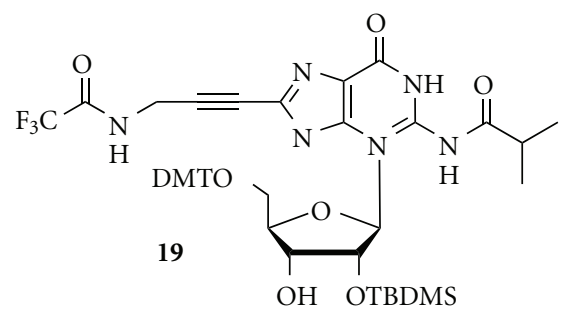
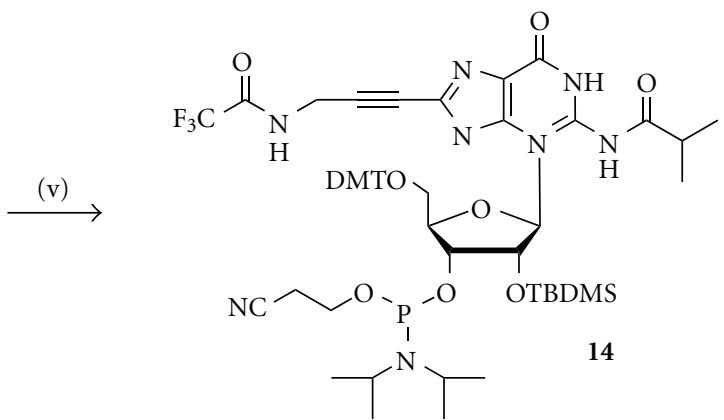

FIgure 4: Synthesis of the guanosine-phosphoramidite. (i) 8-bromoguanosine 15, 2.0 eq. L3, 0.1 eq. Pd(PPh $)_{4}, 0.2$ eq. CuI, 1.2 eq. DIPEA, $40^{\circ} \mathrm{C}, 20 \mathrm{~h} \mathrm{(80 \% );} \mathrm{(ii)} \mathrm{16,} \mathrm{pyridine,} 8.2$ eq. TMS-Cl, $0^{\circ} \mathrm{C}, 2 \mathrm{~h}, 2.2$ eq. isobutyric anhydride, rt, $2 \mathrm{~h}, \mathrm{NH}_{3}$ up to $2.5 \mathrm{M}, 0^{\circ} \mathrm{C}$; (iii) 17 , pyridine, 1.5 eq. DMT-Cl, $0^{\circ} \mathrm{C}, 2.5 \mathrm{~h}$; (iv) 18, THF, 3.7 eq. pyridine, 1.5 eq. $\mathrm{AgNO}_{3}, 15 \mathrm{~min}, 1.7$ eq. TBDMS-Cl, rt, $8.5 \mathrm{~h}$; (v) 19, DCM, 4 eq. DIPEA, 1.5 eq. 2 -cyanoethyl- $N, N$-diisopropylchlorophosphoramidite, $\mathrm{rt}, 2.5 \mathrm{~h}$. 
Several of the prepared phosphoramidite building blocks were successfully incorporated into oligonucleotides using standard solid phase chemistry (Table 1) [17]. The modified phosphoramidites were thoroughly dried by repetitive coevaporating with dichloromethane. After solving the amidite in dry acetonitrile to a concentration of 0.1 to $0.15 \mathrm{M}$, molecular sieves were added and the solution was kept at room temperature for one hour prior to use. Aminomodified phosphoramidites were coupled for $5 \mathrm{~min}$, as were the standard building blocks. The coupling yield was in the $99 \%$ range, comparable with those of the unmodified phosphoramidites. After synthesis, oligonucleotides were deprotected under standard conditions [17], leading also to removal of the TFA group protecting the aliphatic amine of the linker. Purification was carried out by gel electrophoresis, followed by MALDI-TOF MS analysis. Table 4 shows some example masses of MALDI-TOF-MS determination for some synthesized RNA oligonucleotides.

3.3. Postsynthetic Labeling. The amino-modified RNAs were subsequently used for attachment of various dyes. Due to selective reaction of activated carboxylic acids with aliphatic amines, the fully deprotected RNA was used without the danger of significant side reactions at the sugar hydroxyl groups or aromatic amino groups of the bases. In majority, activate esters of Cy5, ATTO647N and Alexa488 were used for postsynthetic labeling (Figure 5).

For Cy5 and ATTO647N, N-hydroxy-succinimidyl (NHS) esters were used. For Alexa488, the NHS-ester is only available as anisomeric mixture of 5- and 6-esters (Figure 6). After reaction with the dye, RNAs labeled with either isomer can be separated by gelelectrophoresis. However, we found it being more efficient using the tetrafluorophenyl (TFP) ester of Alexa488, which is available as the pure 5-isomer (Figure 6).

For each coupling reaction, an amount of 5 to $10 \mathrm{nmol}$ RNA was dissolved in borax buffer at $\mathrm{pH} 8.7$ for labeling with $\mathrm{Cy} 5$ and ATTO647N and $\mathrm{pH} 9.4$ for reaction with Alexa488. The dyes were added dissolved in DMF, and the reaction was carried out at room temperature overnight in the dark. Afterwards, the excess of dye was removed by gel filtration. Purification of dye-labeled RNAs was carried out by PAGE (Cy5- and Alexa488-labeled strands) or by RP-HPLC (ATTO647N-labeled oligonucleotides). Successful labeling was confirmed by MALDI-TOF MS analysis. The data shown in Table 5 are representative examples of MS analyzed dye labeled oligonucleotides.

Figure 7 shows the MALDI-TOF-MS spectra of the oligonucleotide 2-L3-A prior to and after labeling with ATTO647N, as an example for the superior quality of the labeled oligonucleotides.

3.4. Hybridization of Single-Stranded RNAs for Structural Studies. To demonstrate that the amino linkers as well as the fluorescent labels do not intervene in the hybridization of single-stranded oligonucleotides, the hybrid of Alexa Fluor 488-labeled D1L3 and the complementary Cy5-labeled A1L3 was prepared (Figure 8). The oligonucleotides and their hybrid were visualized by illumination with UV-light at 254 and $365 \mathrm{~nm}$. As can be seen from the gel, the two dye-labeled single-stranded oligonucleotides were fully hybridized.

In a parallel experiment, Alexa488-labeled D1L3 and Cy5-labeled A1L3 were dissolved in $\mathrm{KH}_{2} \mathrm{PO}_{4}-\mathrm{K}_{2} \mathrm{HPO}_{4}$ buffer containing $\mathrm{MgCl}_{2}$ and $\mathrm{KCl}$, according to the required buffer conditions in the FRET experiments to be conducted. The mixture was mixed, incubated at $78^{\circ} \mathrm{C}$ for 3 minutes, and slowly cooled down to room temperature. Reaction analysis by native polyacrylamide gel electrophoresis (data not shown) confirmed quantitative hybridization. Several of the synthesized RNAs upon hybridization to their complementary strands were used in fluorescence measurements, in particular in single molecule detection (SMD) and time correlated single photon counting (TCSPC) bulk experiments [14].

3.5. Synthesis of an Activated FMN Derivative for Postsynthetic Labeling of Amino-Functionalized RNA. In previous work, we have engineered an FMN responsive hairpin aptazyme that can be switched on and off in a reversible mode [10]. As we have shown, FMN can be removed from its binding pocket by reduction of the isoalloxazine ring, which is associated with a change in geometry and subsequently with loss of binding. In the original system, FMN was externally added, requiring a 400 -fold excess to saturate its binding site in the aptazyme and to obtain a functional response. Current work is focused on engineering a hairpin aptazyme with FMN being covalently attached via a suitable linker. This small molecular device is supposed to be advantageous in terms of entropic costs for FMN binding to the aptamer and iterative cycles of reversible switching. For this purpose, a suitable FMN derivative for postsynthetic labeling of amino-modified RNA was synthesized. Recent experiments with different FMN derivatives have shown that only the isoalloxazine ring system is required for interaction with the aptazyme, while the ribose unit as well as the phosphate do not seem to play a major role (T. Marschall and S. Müller, unpublished observation). Thus, we decided to attach a carboxyl group containing linker to the ribose chain of riboflavin which subsequently could be postsynthetically attached to amino-functionalized RNA as described in Figures 5, 9, and 10.

Starting from riboflavin, first a fully protected riboflavin derivative was synthesized. Protection of the $5^{\prime}-\mathrm{OH}$ group was achieved by chemoselective tritylation of the primary hydroxyl group with DMT-Cl in pyridine. The remaining secondary hydroxyl groups were reacted with acetic anhydride to give the fully protected derivative $\mathbf{2 2}$ in good yields (83-90\%). The selective deprotection of the $5^{\prime}-\mathrm{OH}$ group under acidic conditions (2\% DCA in DCM) led to the formation of a side product with the same molecular mass as the main product. This suggested the migration of one of the acetyl groups under DMT deprotection conditions. It has been shown before that under acidic conditions, the acetyl group of the $\mathrm{C}^{\prime}-\mathrm{OH}$ group can move to the neighbouring $\mathrm{C}^{\prime}-\mathrm{OH}$ group [24]. Separation of the two isomers by column chromatography on silica gel was not successful. Therefore, we looked for alternative procedures. Alternatively to acids, also $\mathrm{ZnBr}_{2}$ has been suggested as superior reagent 
TABLE 4: Masses of the synthetic RNAs determined by MALDI-TOF-MS (linear negative-ion mode, found $\mathrm{M}=[\mathrm{M}-\mathrm{H}]^{-}$).

\begin{tabular}{lcccc}
\hline Sequence & Cal. mass & Found mass & $\Delta \mathrm{m}$ & Error $(\%)$ \\
\hline L2-TEST & 2677.73 & 2675.99 & 0.77 & 0.64 \\
2-L3-A & 2585.63 & 2583.99 & 0.43 & 0.024 \\
8-L1-A & 2526.53 & 2525.96 & 0.53 & 0.017 \\
A1L1 & 8041.95 & 8040.41 & 0.88. & 0.010 \\
A1L2 & 8155.03 & 8153.15 & 0.30 & 0.011 \\
A1L3 & 8039.93 & 8039.23 & 3.36 & 0.003 \\
A2L1 & 8041.95 & 8044.29 & 2.24 & 0.040 \\
A2L3 & 8039.93 & 8041.17 & 0.69 & 0.030 \\
D1L1 & 8098.93 & 8098.62 & 0.43 & 0.010 \\
D1L2 & 8212.03 & 8211.46 & 3.80 & 0.040 \\
D1L3 & 8096.93 & 8099.73 & & \\
\hline
\end{tabular}

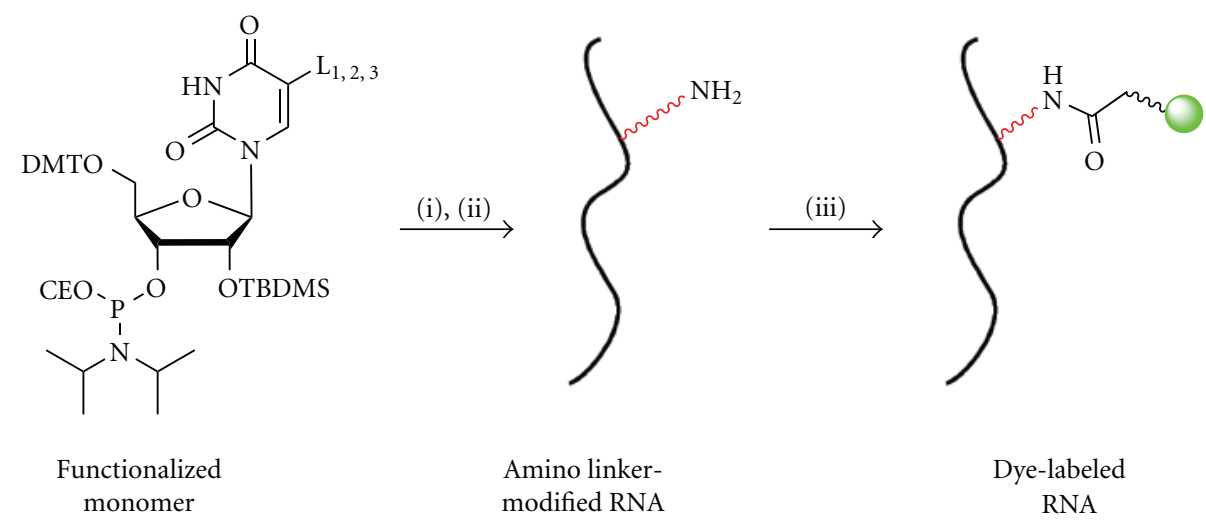

FIgURe 5: Postsynthetic labeling of amino-modified oligonucleotides: (i) Chemical synthesis of amino-modified RNA; (ii) Deprotection; (iii) Postsynthetic labeling with fluorescent dyes.

for removal of DMT groups $[25,26]$. Indeed, using $\mathrm{ZnBr}_{2}$ in dry nitromethane led to the formation of the desired product 23 within a few minutes, without acetyl migration. However, during purification of the detritylated riboflavin derivative by column chromatography, again migration of acetyl protecting groups was observed. Therefore, the solid crude product was just washed several times with ice cold diethyl ether, yielding compound 23 with satisfying purity.

For the synthesis of the carboxylic acid containing linker component, tetraethylene glycol was reacted with tert-butyl acrylate (Figure 10). The product of this Michael addition was converted to the corresponding phosphoramidite with 2cyanoethyl- $N, N$-diisopropropylchlorophosphoramidite by standard procedures [27]. The coupling reaction between the riboflavin derivative 23 and the linker phosphoramidite 26 was accomplished in acetonitrile with BMT activation followed by oxidation with an aqueous solution of iodine to give the flavinmononucleotide derivative 27. The fully protected FMN derivative was treated with trifluoroacetic acid in dichloromethane to eliminate the acid labile tertbutyl protecting group (28). After the purification of the free acid form of the FMN derivative by RP-HPLC, cleavage of the $\beta$-cyanoethyl and the acetyl groups was achieved by stirring in $30 \%$ ammonia in methanol. Evaporation of the ammonia solution and subsequent treatment with DOWEX $\left(\mathrm{H}^{+}\right.$-form $)$ yielded the desired product 29 that upon activation as NHS ester was used for postsynthetic RNA functionalization.

The FMN sensitive hairpin aptazyme was chemically synthesized as a three-stranded or two-stranded system using the phosphoramidite approach. In order to facilitate coupling of the FMN derivative with the oligonucleotides, 2 -aminouridine or 5-propargylaminouridine (Figure 11) were introduced in predefined positions of the RNA chain, providing the aliphatic amine for selective attachment of the FMN derivative (Table 3). Suitable positions for FMN attachment have been defined on the basis of the structure model of the FMN aptamer [28] with the help of PyMOL.

In order to couple the FMN derivative to the aminomodified RNA, an NHS-ester was generated in situ by reacting the unprotected FMN derivative 29 with $1.2 \mathrm{eq}$. TSTU and 2 eq. DIPEA for one hour at room temperature in DMF (Figure 12). The formation of the activated ester was monitored by MALDI mass spectrometry. After all of the free carboxylic acid had been converted to its NHS-form, the FMN derivative was coupled to the amino group bearing oligonucleotide. Successful coupling was confirmed by polyacrylamide gel electrophoresis (Figure 12). The functional characterization of the resulting FMN-RNA constructs in ribozyme activity assays is currently in progress. 
<smiles>Nc1ccc2c(c1[N+](=O)[O-])Cc1c(ccc(N)c1[N+](=O)[O-])C2=C1C=CC(N)C(=O)C1=O</smiles>

Alexa fluor 488 5(6)-NHS-ester

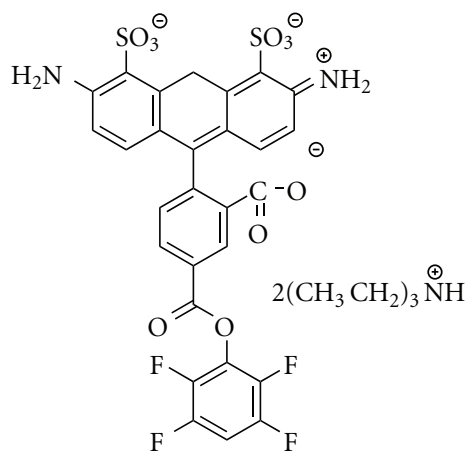

Alexa fluor 488 5-TFP-ester<smiles>CCN1c2ccc(O)cc2C(C)(C)C1/C=C/C=C/C=C1/N(CCCCCC(=O)ON2C(=O)CCC2=O)c2ccc([O-])cc2C1(C)C</smiles>

FIGURE 6: Activated derivatives of fluorescent dyes for postsynthetic labeling of RNA.

TABLE 5: Masses of dye-labeled oligonucleotides determined by MALDI-TOF-MS (linear negative-ion mode, found $\mathrm{M}=[\mathrm{M}+\mathrm{H}]^{-}$).

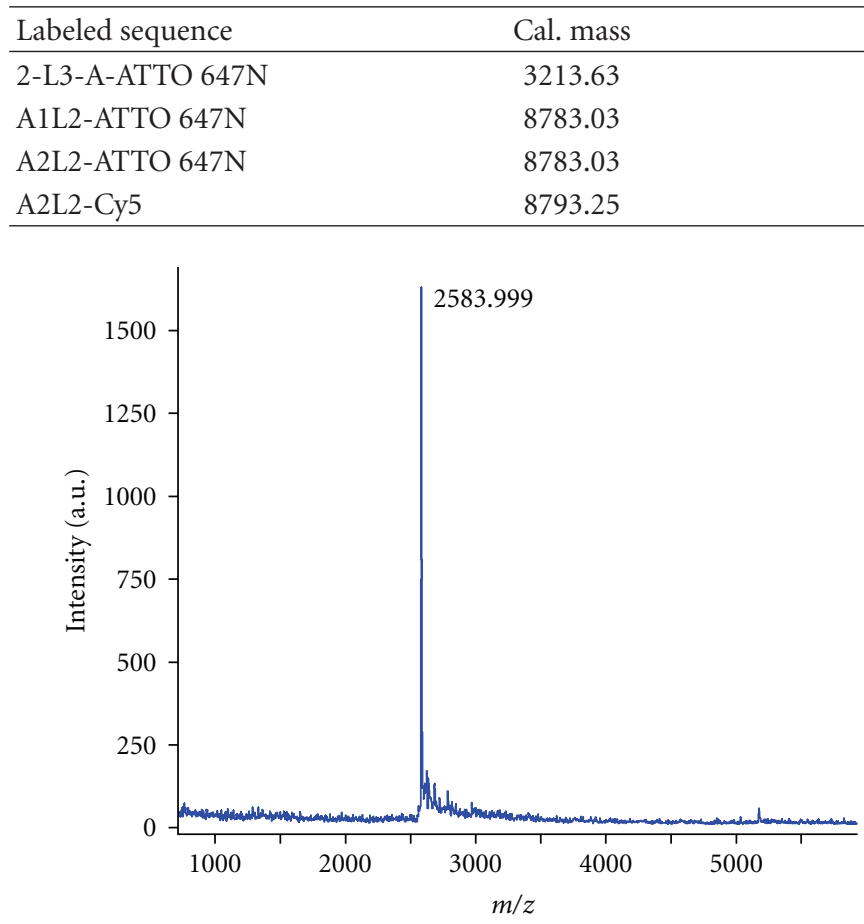

(a)

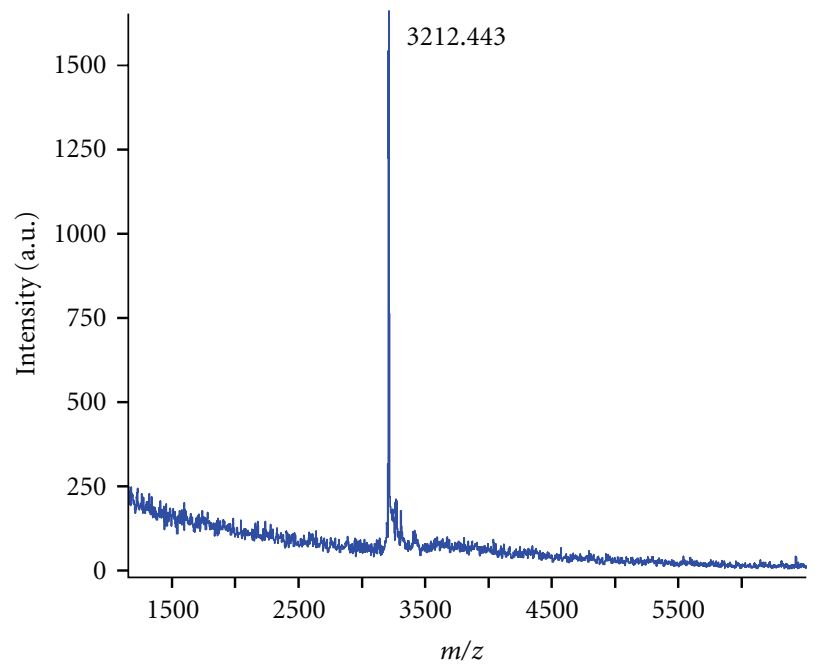

(b)

Figure 7: MALDI-TOF mass spectra of the amino-modified oligonucleotide 2-L3-A (a) and its corresponding conjugate with ATTO647N (b). For the sequence of 2-L3-A, compare Table 1. 


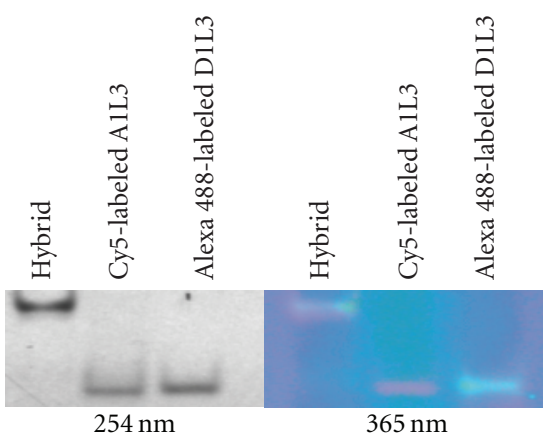

Donor 9

5'-GGCGGUGCCGACUGCGAGCUUGCC A- $3^{\prime}$ Alexa 488-labeled D1L3

3'-CCGCCACGGCUGACGCUCGAACGGU-5' Cy5-labeled A1L3

○ Acceptor

FIgURE 8: Hybridization of Alexa488-labeled D1L3 and Cy5-labeled A1L3: $3 \mu \mathrm{M}$ Alexa488-labeled D1L3: $3 \mu \mathrm{M}$ Cy5-labeled A1L3, 10 mM $\mathrm{MgCl}_{2}, 50 \mathrm{mM}$ Tris buffer, $\mathrm{pH} 7.4$, total volume $100 \mu \mathrm{L}, 78^{\circ} \mathrm{C} 3 \mathrm{~min}$, slowly cooling to rt. The hybrid was analyzed by $15 \%$ native PAA-gel: (left) illuminated at $254 \mathrm{~nm}$, (right) illuminated at $365 \mathrm{~nm}$.<smiles>Cc1cc2nc3c(=O)[nH]c(=O)nc-3n(CC(O)C(O)C(O)CO)c2cc1C</smiles><smiles>CCOCC(O)C(O)Cn1c2nc(=O)[nH]c(=O)c-2nc2cc(C)c(C)cc21</smiles><smiles>CCOCC(OC(C)=O)C(Cn1c2nc(=O)[nH]c(=O)c-2nc2cc(C)c(C)cc21)OC(C)=O</smiles><smiles>CC(=O)OC(CO)C(Cn1c2nc(=O)[nH]c(=O)c-2nc2cc(C)c(C)cc21)C(C)=O</smiles>

FIGURE 9: Synthesis of protected riboflavine derivatives: (i) DMT-Cl, DMAP, pyridine, rt, overnight (53\%); (ii) acetic anhydride, pyridine, $0^{\circ} \mathrm{C} \rightarrow \mathrm{rt}$, overnight (90\%); (iii) $\mathrm{ZnBr}_{2}$ in nitromethane, 2 min (83\%).

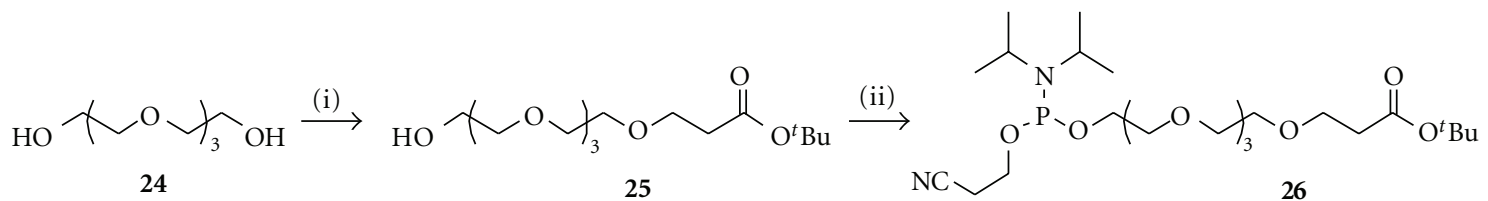<smiles>[R10]OC(=O)CCOCCOCC(C)OP([R20])(=O)OCC([R20])C([R20])C([R20])Cn1c2nc(=O)[nH]c(=O)c-2nc2cc(C)c(C)cc21</smiles>

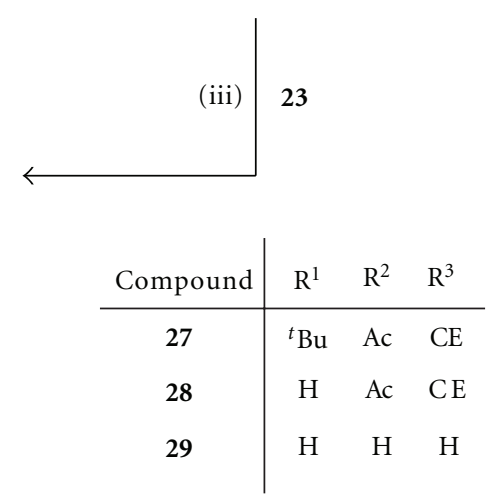

FIGURE 10: Synthesis of the fully protected linker unit: (i) Na, tert-butyl acrylate, THF, rt, $1 \mathrm{~d}$ (34\%); (ii) 2-Cyanoethyl- $N$, $N$-diisopropropylchlorophosphoramidite, DIPEA, DCM, rt, $1.5 \mathrm{~h}$ (quant.); (iii) (a) BMT, MeCN, rt, 1 h; (b) $0.2 \mathrm{M} \mathrm{I}_{2}$ in THF/pyridine/ $\mathrm{H}_{2} \mathrm{O}(2: 1: 1)(32 \%)$. 


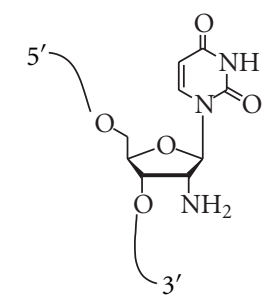

$2^{\prime}$-Aminouridine (AMU)

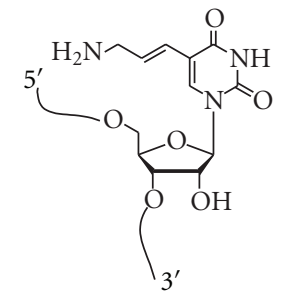

5-(3-Aminopro-1-enyl) uridine (APU)

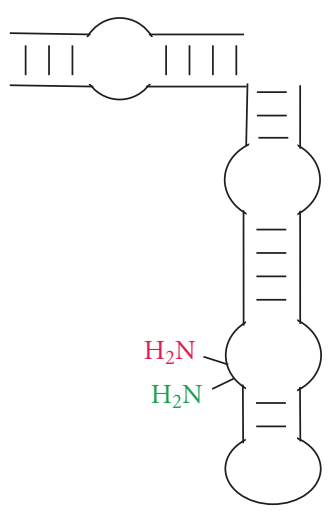

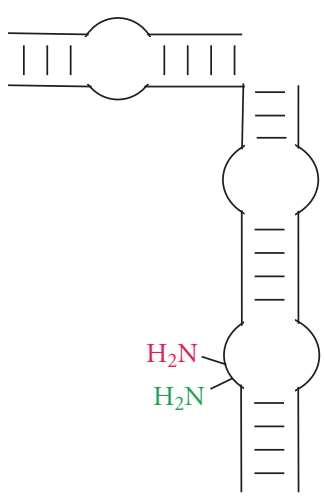

(b)

FIGURE 11: (a) Structure of the two nucleotide analogs used for the incorporation of an aliphatic amino group into the aptazyme RNA. (b) Two-stranded (left) and three-stranded (right) aptazyme. The modifications AMU and APU are located at position U12 (red) and U14 (green), respectively.

3.6. Synthesis of Specifically Spin-Labeled RNAs. Within a collaborative project on structural analysis of the tetracycline dependent riboswitch [9] and of the FMN responsive aptazyme described above [10] by electron paramagnetic resonance (EPR) spectroscopy, we have synthetically prepared RNAs carrying a suitable spin label at a predefined site. The basic strategy of site-directed spin-labeling originally has been developed with proteins and involves modification of the $\mathrm{SH}$ group of an appropriate cysteine with a selective paramagnetic nitroxide reagent. Applying the same technique to RNA, labeling initially was achieved by incorporating a guanosine monophosphorothioate at the $5^{\prime}$-end followed by spin-labeling at the sulfur [29]. The strategy was extended towards site-specific introduction of a phosphorothioate group at RNA backbone locations or of modified bases such as 4-thiouridine and subsequent attachment of a suitably activated nitroxide spin label [30-32]. More recent work employs aliphatic amino groups at the 2 -position of a specific sugar residue or attached at the heterocyclic base [33-35].

We have made use of two different strategies, incorporating either 4-thiouridine or $2^{\prime}$-aminouridine into RNA followed by postsynthetic reaction with the nitroxide spin label. For reaction with 4-thiouridine containing RNAs, (1-oxyl-2,2,5,5-tetramethylpyrroline-3-methyl)methanethiosulfonate (TPM-MTS) and N-(1-oxyl- 2,2,5,5-tetramethyl3 -pyrrolidinyl) iodoacetamide (TMP-IAA) was used, for reaction with $2^{\prime}$-aminouridine containing RNA, (1oxyl2,2,5,5-tetramethylpyrrolin-3-carboxylate) - $N$-hydroxysuccinimidyl ester (TMC-NHS) or 4-isocyanato-2,6-tetramethylpiperidylN-oxid (TEMPO-NCO) (Figure 13). As mentioned already above, the 12 modified RNAs VW1 to VW12 shown in Table 2 were synthesized within a structural study of a tetracycline responsive RNA aptamer [9]. HPAS11 and HPAS16 were synthesized and spin labeled for an EPR study of an artificial flavin mononucleotide responsive riboswitch [10].

For RNAs labeled via 4-thiouridine, reaction with the TPM-MTS spin label was favored, because initial EPR measurements showed that the TMP-IAA label has suboptimal properties, presumably because it is too mobile due to the rather flexible $\mathrm{CH}_{2}-\mathrm{CO}-\mathrm{NH}-\mathrm{CH}_{2}$-spacer (Figure 13, lower part). Therefore, the majority of 4 -thiouridine containing RNAs was reacted with TPM-MTS for introduction of the less mobile nitroxide spin label. The yields shown in Table 2 were reproduced in up to five labeling reactions for each individual RNA. Thus, the variation of labeling efficiency observed for individual RNAs suggests that the structure of the RNA aptamer significantly influences the labeling reaction, making spin labeling of individual uridines dependent on the specific location in the aptamer sequence.

A second point that may account for the observed low labeling efficiency is the rather unstable disulfide bond attaching the spin label at the uracil residue. Therefore, as an alternative, we have also studied conditions for spin labeling via the RNA sugar-phosphate backbone (Figure 14). To this end, RNAs containing $2^{\prime}$-aminouridine at a specific position (HPAS11 to HPAS16) were synthesized and labeled using either TEMPO-NCO or TMC-NHS. It has been described in the literature that the steric hindrance of the $2^{\prime}-\mathrm{NH}_{2}-$ group hampers reaction with NHS esters [36]. Therefore, we have extended the reaction time from 15 minutes to 4 hours and used a 500-fold excess of the NHS-reagent to overcome the problem of low reaction yields. On the contrary to NHS esters, isocyanates were shown to virtually quantitatively react with $2^{\prime}$-amino sugars [33]. However, being less selective, side reactions at the nucleobases were observed when a high excess of the isocyanate reagent was used [37]. The authors have optimized reaction conditions such that a $2^{\prime}$-amino group was selectively modified without concurrent side reaction. In that, they observed an increase of the yield of the modified oligonucleotide upon lowering the temperature, which presumably is the result of repression of competing isocyanate hydrolysis [37]. In parallel rows of labeling reactions under varying conditions, we have also looked at reaction conditions to deliver the spin-labeled RNA with high yield and high quality. Best results were obtained with an only 15 -fold excess of the isocyanate reagent over $\mathrm{RNA}$, and a reaction temperature of $-8^{\circ} \mathrm{C}$. Under these conditions, about $80 \%$ labeling efficiency were reproducibly 
<smiles>Cc1cc2nc3c(=O)[nH]c(=O)nc-3n(CC(O)C(O)C(O)COP(=O)(O)OCCOCCOCCOCCOCCC(=O)O)c2cc1C</smiles>

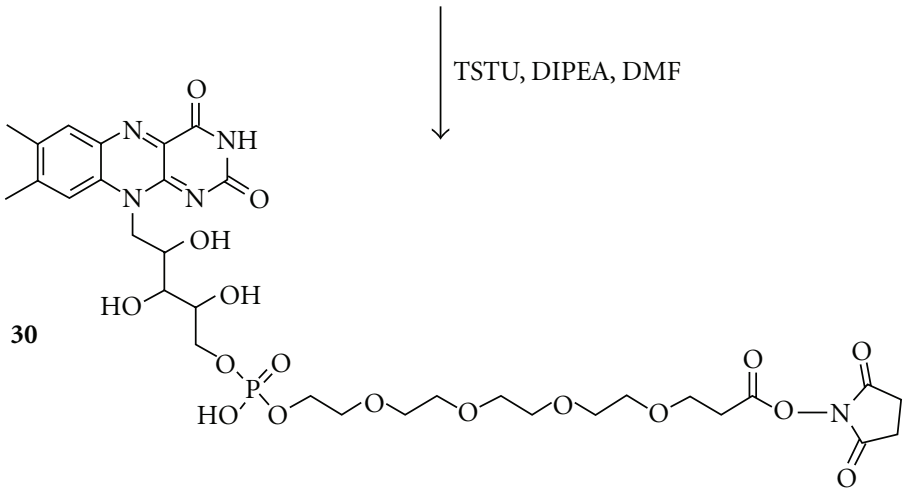

(a)

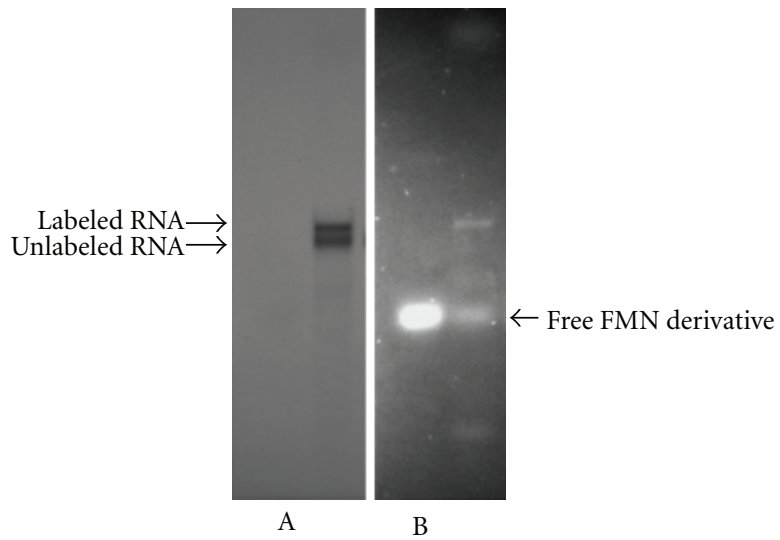

(b)

FIgURE 12: (a) Formation of the N-hydroxysuccinimidyl (NHS) ester. (b) PAGE analysis of the coupling reaction between amino-modified RNA HPAT1-BHI (for sequence see Table 3) and the FMN derivative. Visualization is at UV $254 \mathrm{~nm}$ (A) and $365 \mathrm{~nm}$ (B).

obtained for both labeling reagents with all RNA samples (Table 2). In order to avoid side reactions, we have added the spin label reagent only once in 15 -fold excess even though it was originally described that repeated additions of the reagent give nearly quantitative results [33]. EPR spectra of RNAs showed that the spin labels conjugated via the $2^{\prime}$ amino group are rather immobile (H.-J. Steinhoff, University Osnabrück, oral information), making labeling via this position most favorable. It was somewhat surprising that mobility of TEMPO seemed to be even more limited than that of the TPC- label, because the 6-membered piperidyl ring is conformationally more flexible than the 5-membered pyrroline ring. Obviously, the nature of the spacer unit (urea versus amide bond) also has a strong influence. Overall, in the specific context of RNA sequences shown in Table 2, $2^{\prime}$-amino sugar labeling is advantageous over 4-thiouridine labeling in terms of efficiency and immobility.

\section{Conclusion}

As demonstrated above, the chemical synthesis of RNA offers the possibility of site-specific introduction of modified nucleosides. This is an important advantage over enzymatic procedures, making RNA synthesis an essential tool for a large number of studies in different fields. We have succeeded in the synthesis of a number of monomer building blocks that upon incorporation in RNA allow for postsynthetic attachment of spectroscopic reporter groups or other desired functionalities. The amino-modified monomers presented in this paper are a valuable addition to the RNA chemist's tool box. Due to the different length and flexibility of the linkers that carry the aliphatic amino groups for postsynthetic functionalization, molecular entities that become attached to the RNA have differing degrees of motional freedom. This is of particular interest for fluorescence spectroscopic studies, because systematic errors may result from fluorescence dyes that are sterically hindered, or on the contrary are too mobile, limiting the accuracy of the measurement. Therefore, using our amino linker building blocks of the $U$ series (Figure 2), an extensive analysis of the influence of the linker lengths and rigidity on the accuracy of FRET measurements was carried out [14]. The results will pave the way for more sophisticated studies of RNA structure dynamics. Likewise, EPR spectroscopic analysis of RNA will profit from the new building blocks, since spin labels attached to the RNA of interest, are subjected to the same conditions and restrictions as the fluorescent dyes in fluorescence spectroscopy.

Lastly, we have synthesized an FMN-RNA conjugate to be used for functional studies of an FMN responsive aptazyme. This example shows that there is much room for RNA engineering and construction of sophisticated RNA devices. Organic chemistry offers a large number of possibilities to prepare suitably activated modifiers that can be postsynthetically attached to amino-modified RNA, or to RNA carrying other functionalities such as for example thiol groups, or alkynes and azides as used for labeling by Click chemistry [38]. Thus, in combination with the development of synthetic routes to appropriately activated modifiers, RNAs can be conjugated with a large variety of tags, making the nucleic acid not only visible in spectroscopic 

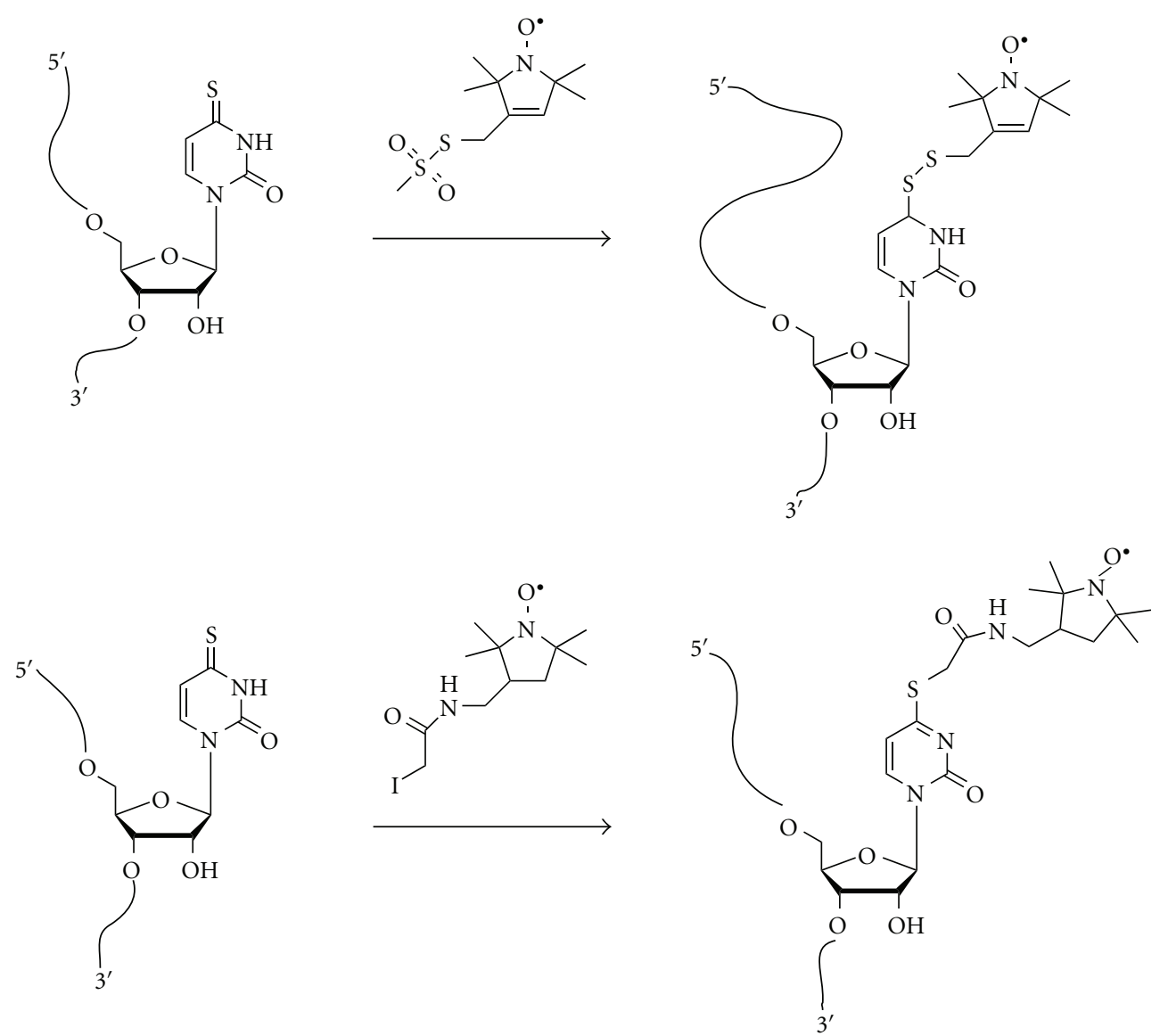

FIGURE 13: Strategy for postsynthetic introduction of spin labels to 4-thiouridine containing RNA.
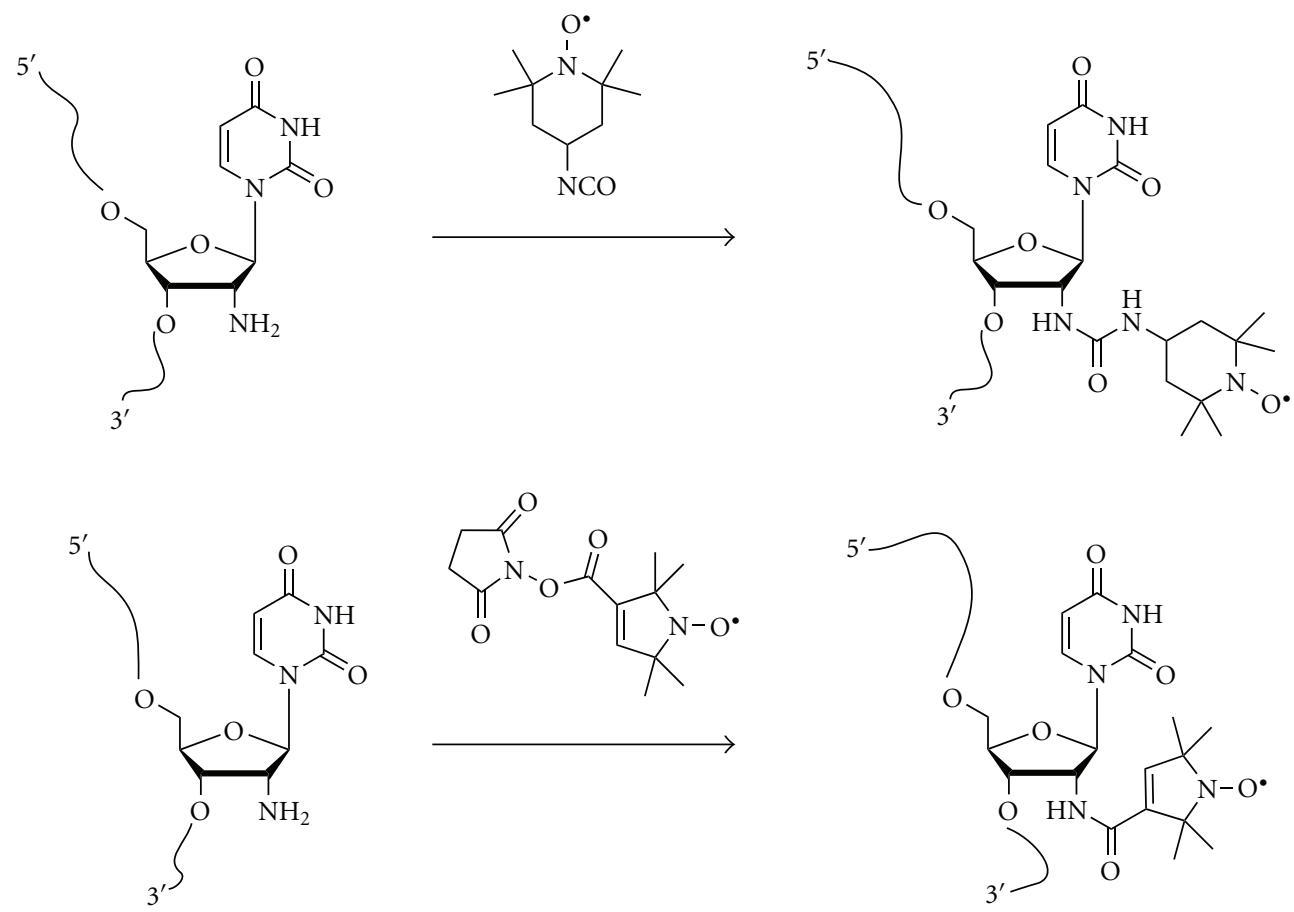

FIGURE 14: Labeling of the $2^{\prime}$-amino group of a model RNA. 
experiments, but also adding new functionality as demonstrated with the RNA-FMN conjugate described herein.

\section{Abbreviations}

$\begin{array}{ll}\text { CE: } & \text { Cyanoethyl } \\ \text { DCM: } & \text { Dichloromethane } \\ \text { DIPEA: } & \text { Diisopropylethylamine } \\ \text { DMA: } & \text { Dimethylamine } \\ \text { DMAP: } & \text { Dimethylaminopyridin } \\ \text { DMF: } & \text { Dimethylformamide } \\ \text { DMT: } & \text { Dimethoxytrityl } \\ \text { MeCN: } & \text { Acetonitril } \\ \text { TBDMS: } & \text { tert-butyldimethylsilyl } \\ \text { TEA: } & \text { Triethylamine } \\ \text { BMT: } & 1 \text {-(Benzylmercapto)-1H-tetrazole } \\ \text { TEMPO-NCO: } & \text { 4-isocyanato-2,6-tetramethylpiperidyl- } \\ & \text { N-oxyl } \\ \text { TFA: } & \text { Trifluoroacetic acid } \\ \text { TMC-NHS: } & \text { (1-oxyl-2,2,5,5-tetramethylpyrrolin-3- } \\ & \text { carboxylat)- } N \text {-hydroxysuccinimidyl } \\ & \text { ester } \\ \text { TMP-IAA: } & \text { N-(1-oxyl-2,2,5,5-tetramethyl-3- } \\ & \text { pyrrolidinyl) } \\ & \text { iodoacetamide } \\ \text { TPM-MTS: } & \text { (1-oxyl-2,2,5,5-tetramethylpyrroline-3- } \\ & \text { methyl)methanethiosulfonate. }\end{array}$

\section{References}

[1] A. Mescalchin and T. Restle, "Oligomeric nucleic acids as antivirals," Molecules, vol. 16, no. 2, pp. 1271-1296, 2011.

[2] I. Drude, V. Dombos, S. Vauléon, and S. Müller, "Drugs made of RNA: development and application of engineered RNAs for gene therapy," Mini-Reviews in Medicinal Chemistry, vol. 7, no. 9, pp. 912-931, 2007.

[3] J. Liu, Z. Cao, and Y. Lu, "Functional nucleic acid sensors," Chemical Reviews, vol. 109, no. 5, pp. 1948-1998, 2009.

[4] F. Meng, W. E. Hennink, and Z. Zhong, "Reduction-sensitive polymers and bioconjugates for biomedical applications," Biomaterials, vol. 30, no. 12, pp. 2180-2198, 2009.

[5] S. Müller, J. Wolf, and S. A. Ivanov, "Current strategies for the synthesis of RNA," Current Organic Synthesis, vol. 1, no. 3, pp. 293-307, 2004.

[6] M. H. Caruthers, "A brief review of DNA and RNA chemical synthesis," Biochemical Society Transactions, vol. 39, no. 2, pp. 575-580, 2011.

[7] F. Narberhaus, T. Waldminghaus, and S. Chowdhury, "RNA thermometers," FEMS Microbiology Reviews, vol. 30, no. 1, pp. 3-16, 2006.

[8] T. J. Wilson, M. Nahas, T. Ha, and D. M. J. Lilley, "Folding and catalysis of the hairpin ribozyme," Biochemical Society Transactions, vol. 33, no. 3, pp. 461-465, 2005.

[9] D. Wunnicke, D. Strohbach, J. E. Weigand et al., "Ligandinduced conformational capture of a synthetic tetracycline riboswitch revealed by pulse EPR," $R N A$, vol. 17, no. 1, pp. 182-188, 2011.

[10] D. Strohbach, N. Novak, and S. Müller, "Redox-active riboswitching: allosteric regulation of ribozyme activity by ligandshape control," Angewandte Chemie-International Edition, vol. 45, no. 13, pp. 2127-2129, 2006.
[11] K. A. Cruickshank and D. L. Stockwell, "Oligonucleotide labelling: a concise synthesis of a modified thymidine phosphoramidite," Tetrahedron Letters, vol. 29, no. 41, pp. 52215224, 1988.

[12] S. Dey and T. L. Sheppard, "Ketone-DNA: a versatile postsynthetic DNA decoration platform," Organic Letters, vol. 3, no. 25, pp. 3983-3986, 2001.

[13] C. M. McKeen, L. J. Brown, J. T. G. Nicol, J. M. Mellor, and T. Brown, "Synthesis of fluorophore and quencher monomers for use in Scorpion primers and nucleic acid structural probes," Organic and Biomolecular Chemistry, vol. 1, no. 13, pp. 2267-2275, 2003.

[14] S. Sindbert, S. Kalinin, H. Nguyen et al., "Accurate distance determination of nucleic acids via FRET: implications of dye linker length and rigidity," Journal of the American Chemical Society, vol. 133, no. 8, pp. 2463-2480, 2011.

[15] C. Schmidt, R. Welz, and S. Müller, "RNA double cleavage by a hairpin-derived twin ribozyme," Nucleic Acids Research, vol. 28, no. 4, pp. 886-894, 2000.

[16] R. Welz and S. Müller, "5-(Benzylmercapto)- $1 H$-tetrazole as activator for 2'-O-TBDMS phosphoramidite building blocks in RNA synthesis," Tetrahedron Letters, vol. 43, no. 5, pp. 795797, 2002.

[17] I. Drude, A. Strahl, D. Galla, O. Müller, and S. Müller, "Design of hairpin ribozyme variants with improved activity for poorly processed substrates," FEBS Journal, vol. 278, no. 4, pp. 622$633,2011$.

[18] R. Welz, K. Bossmann, C. Klug, C. Schmidt, H.-J. Fritz, and S. Müller, "Site-directed alteration of RNA sequence mediated by an engineered twin ribozyme," Angewandte ChemieInternational Edition, vol. 42, no. 21, pp. 2424-2427, 2003.

[19] D. Gasparutto, T. Livache, H. Bazin et al., "Chemical synthesis of a biologically active natural tRNA with its minor bases," Nucleic Acids Research, vol. 20, no. 19, pp. 5159-5166, 1992.

[20] F. Wincott, A. DiRenzo, C. Shaffer et al., "Synthesis, deprotection, analysis and purification of RNA and ribozymes," Nucleic Acids Research, vol. 23, no. 14, pp. 2677-2684, 1995.

[21] W. A. Herrmann, C. Brossmer, K. Öfele et al., "Palladacycles as structurally defined catalysts for the heck olefination of chloro- and bromoarenes," Angewandte ChemieInternational Edition, vol. 34, no. 17, pp. 1844-1848, 1995.

[22] K. Shah, H. Y. Wu, and T. M. Rana, "Synthesis of uridine phosphoramidite analogs: reagents for site-specific incorporation of photoreactive sites into RNA sequences," Bioconjugate Chemistry, vol. 5, no. 6, pp. 508-512, 1994.

[23] G. H. Hakimelahi, Z. A. Proba, and K. K. Ogilvie, "New catalysts and procedures for the dimethoxytritylation and selective silylation of ribonucleosides," The Canadian Journal of Chemistry, vol. 60, pp. 1106-1113, 1982.

[24] C. Frier, J.-L. Décout, and M. Fontecave, "Method for preparing new flavin derivatives: synthesis of flavin-thymine nucleotides and flavin-oligonucleotide adducts," Journal of Organic Chemistry, vol. 62, no. 11, pp. 3520-3528, 1997.

[25] V. Kohli, H. Blöcker, and H. Köster, "The triphenylmethyl (trityl) group and its uses in nucleotide chemistry," Tetrahedron Letters, vol. 21, no. 28, pp. 2683-2686, 1980.

[26] M. D. Matteucci and M. H. Caruthers, "The use of zinc bromide for removal of dimethoxytrityl ethers from deoxynucleosides," Tetrahedron Letters, vol. 21, no. 34, pp. 3243-3246, 1980.

[27] T. Atkinson and M. Smith, "Solid phase synthesis of oligodeoxyribonucleotides by the phosphite-triester method," in Oligonucleotide Synthesis: A Practical Approach, M. J. Gait, Ed., IRL Press Oxford, 1984. 
[28] P. Fan, A. K. Suri, R. Fiala, D. Live, and D. J. Patel, "Molecular recognition in the FMN-RNA aptamer complex," Journal of Molecular Biology, vol. 258, no. 3, pp. 480-500, 1996.

[29] J. C. Macosko, M. S. Pio, I. Tinoco Jr., and Y.-K. Shin, "A novel 5'-displacement spin-labeling technique for electron paramagnetic resonance spectroscopy of RNA," RNA, vol. 5, no. 9, pp. 1158-1166, 1999.

[30] P. Z. Qin, K. Hideg, J. Feigon, and W. L. Hubbell, "Monitoring RNA base structure and dynamics using site-directed spin labeling," Biochemistry, vol. 42, no. 22, pp. 6772-6783, 2003.

[31] P. Z. Qin, S. E. Butcher, J. Feigon, and W. L. Hubbell, "Quantitative analysis of the isolated GAAA tetraloop/receptor interaction in solution: a site-directed spin labeling study," Biochemistry, vol. 40, no. 23, pp. 6929-6936, 2001.

[32] A. Ramos and G. Varani, "A new method to detect long-range protein-RNA contacts: NMR detection of electron-proton relaxation induced by nitroxide spin-labeled RNA," Journal of the American Chemical Society, vol. 120, no. 42, pp. 1099210993, 1998.

[33] T. E. Edwards, T. M. Okonogi, B. H. Robinson, and S. T. Sigurdsson, "Site-specific incorporation of nitroxide spinlabels into internal sites of the TAR RNA: structure-dependent dynamics of RNA by EPR spectroscopy," Journal of the American Chemical Society, vol. 123, no. 7, pp. 1527-1528, 2001.

[34] N. Piton, Y. Mu, G. Stock, T. F. Prisner, O. Schiemann, and J. W. Engels, "Base-specific spin-labeling of RNA for structure determination," Nucleic Acids Research, vol. 35, no. 9, pp. 3128-3143, 2007.

[35] T. E. Edwards and S. T. Sigurdsson, "Site-specific incorporation of nitroxide spin-labels into 2'-positions of nucleic acids," Nature Protocols, vol. 2, no. 8, pp. 1954-1962, 2007.

[36] S. B. Cohen and T. R. Cech, "Dynamics of thermal motions within a large catalytic RNA investigated by cross-linking with thiol-disulfide interchange," Journal of the American Chemical Society, vol. 119, no. 27, pp. 6259-6268, 1997.

[37] S. T. Sigurdsson and F. Eckstein, "Site specific labelling of sugar residues in oligoribonucleotides: reactions of aliphatic isocyanates with 2'amino groups," Nucleic Acids Research, vol. 24, no. 16, pp. 3129-3133, 1996.

[38] A. H. El-Sagheer and T. Brown, "Click chemistry with DNA," Chemical Society Reviews, vol. 39, no. 4, pp. 1388-1405, 2010. 

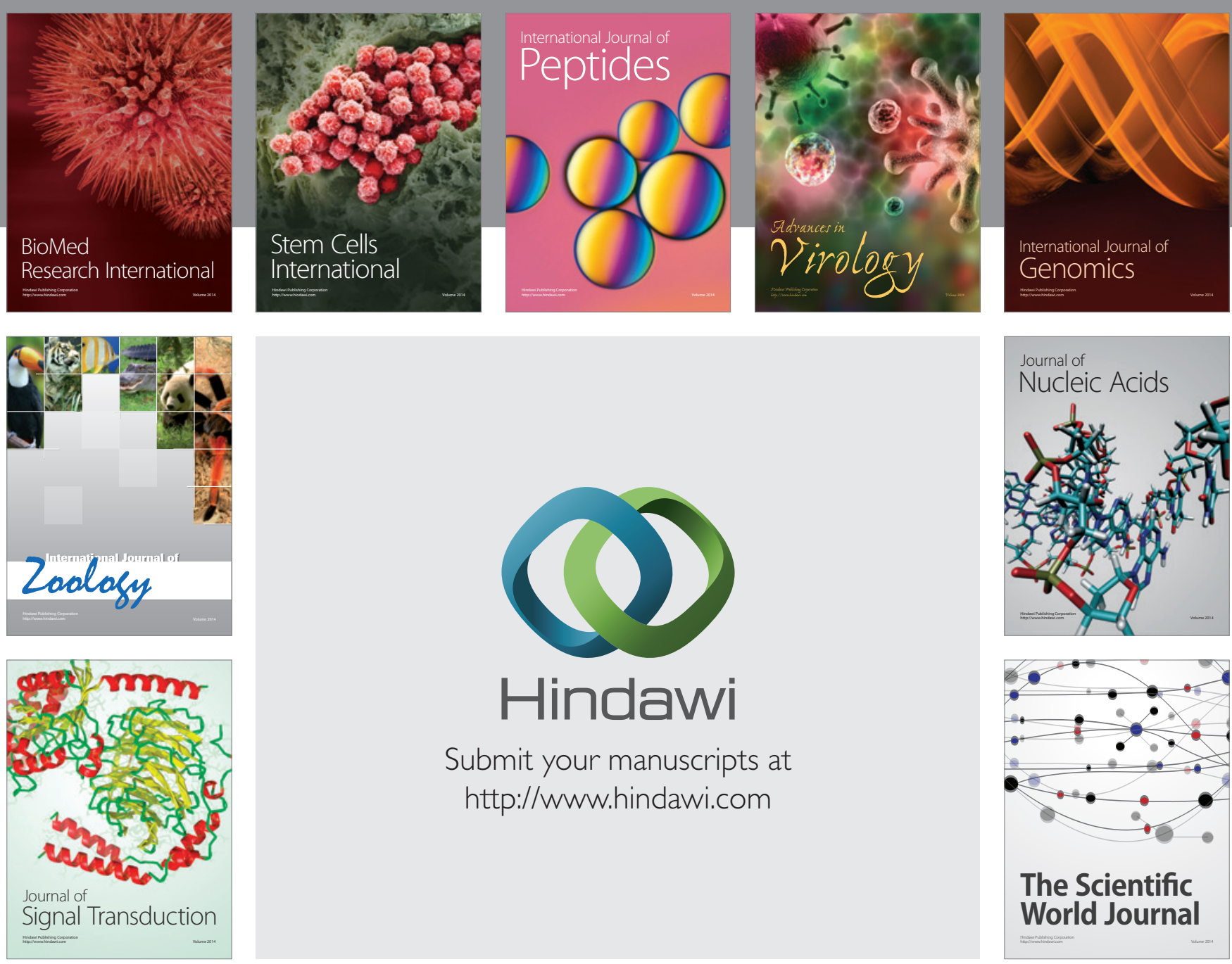

Submit your manuscripts at

http://www.hindawi.com
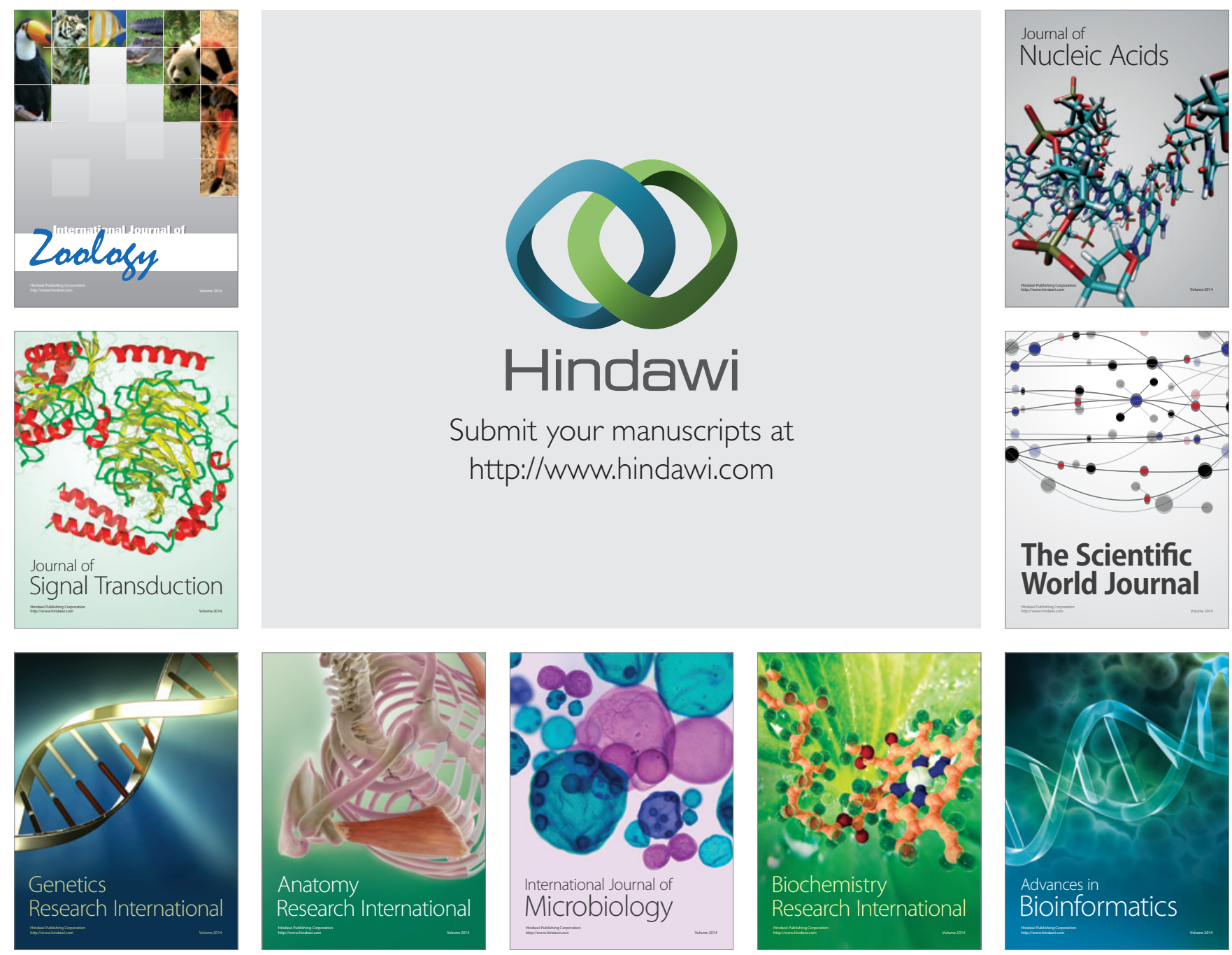

The Scientific World Journal
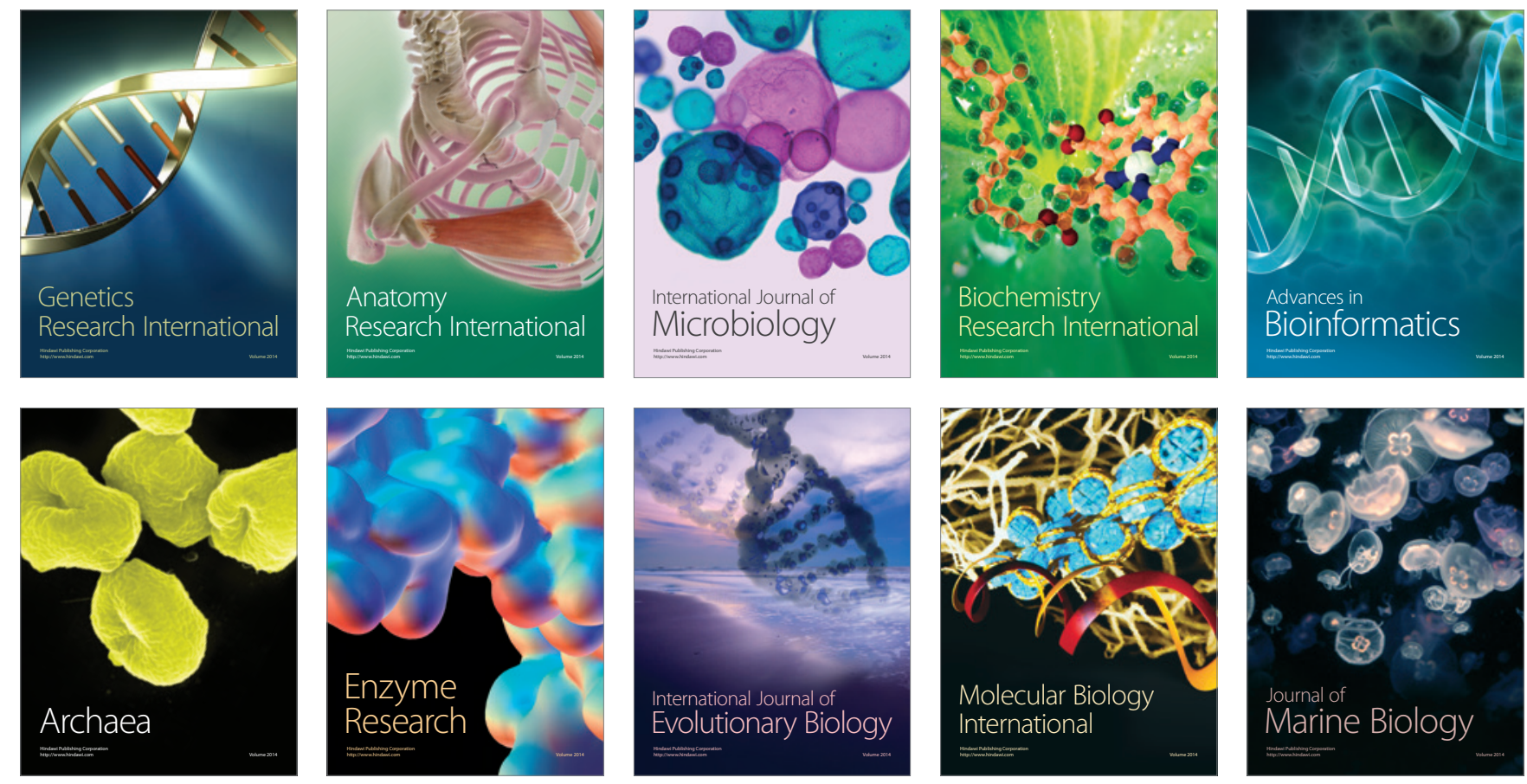